\title{
A gyermekkori koronavírus-fertőzést követő sokszervi gyulladás diagnosztikája és kezelése
}

\author{
Constantin Tamás dr. ${ }^{1}$ - Andrási Noémi dr. ${ }^{1}$ - Ponyi Andrea dr. ${ }^{1}$ \\ Goschler Ádám dr. ${ }^{1}$ - Ablonczy László dr. ${ }^{2}$ - Kincs Judit dr. ${ }^{3}$ \\ Csóka Monika dr. ${ }^{1}$ - Egyed Bálint dr. ${ }^{1}$. Horváth Zsuzsanna dr. ${ }^{1}$ \\ Kalocsai Krisztina dr. ${ }^{3}$ - Káposzta Rita dr. ${ }^{5}$ - Kardics Kinga dr. ${ }^{3}$ \\ Kemény Viktória dr. ${ }^{1}$ - Mosdósi Bernadett dr. ${ }^{5}$. Pék Tamás dr. ${ }^{3}$
}

Szabó Zsófia dr. ${ }^{6}$. Tóth Attila dr. ${ }^{7}$. Tory Kálmán dr. ${ }^{3}$. Tölgyesi Andrea dr. ${ }^{3}$

Ónozó Beáta dr. ${ }^{8}$. Vágó Hajnalka dr. ${ }^{7}$ - Vilmányi Csaba dr. ${ }^{2}$

Peter Weiser dr. ${ }^{9}$ - Szekanecz Zoltán dr. ${ }^{10}$ - Kovács Gábor dr. ${ }^{1}$ - Szabó Attila dr. ${ }^{3}$

\author{
'Semmelweis Egyetem, Általános Orvostudományi Kar, II. Gyermekgyógyászati Klinika, Budapest \\ ${ }^{2}$ Gottsegen György Országos Kardiológiai Intézet, Budapest \\ ${ }^{3}$ Semmelweis Egyetem, Általános Orvostudományi Kar, I. Gyermekgyógyászati Klinika, Budapest \\ ${ }^{4}$ Debreceni Egyetem, Általános Orvostudományi Kar, Gyermekgyógyászati Klinika, Debrecen \\ ${ }^{5}$ Pécsi Tudományegyetem, Általános Orvostudományi Kar, Gyermekgyógyászati Klinika, Pécs \\ ${ }^{6}$ Semmelweis Egyetem, Immunológiai Laboratórium, Budapest \\ ${ }^{7}$ Semmelweis Egyetem, Általános Orvostudományi Kar, Városmajori Szív- és Érgyógyászati Klinika, Budapest \\ ${ }^{8}$ Borsod-Abaúj-Zemplén Megyei Központi Kórház és Egyetemi Oktatókórház, \\ Velkey László Gyermekegészségügyi Központ, Miskolc \\ ${ }^{9}$ University of Alabama, Department of Pediatrics, Birmingham, Alabama, USA \\ ${ }^{10}$ Debreceni Egyetem, Általános Orvostudományi Kar, Reumatológiai Tanszék, Debrecen
}

\begin{abstract}
A SARS-CoV-2-fertőzés ritka gyermekkori szövődménye a sokszervi gyulladás, angol terminológiával paediatric inflammatory multisystem syndrome (PIMS). Két vagy több szerv érintettségével járó, súlyos tünetekkel induló betegségről van szó, amelynek tünetei átfedést mutatnak a Kawasaki-betegséggel, a toxikus sokk szindrómával és a makrofágaktivációs szindrómával. A PIMS-betegek intenzív terápiás osztályon vagy intenzív terápiás háttérrel rendelkező intézményben kezelendők, ahol biztosítottak a kardiológiai ellátás feltételei is. A szükséges immunterápia a klinikai prezentációtól függ. A jelen közleményben a szerzők a releváns nemzetközi irodalom áttekintését követően ajánlást tesznek a PIMS diagnosztikai és terápiás algoritmusára.
\end{abstract}

Orv Hetil. 2021; 162(17): 652-667.

Kulcsszavak: PIMS, sokszervi gyulladás, diagnosztika, terápia

\section{Diagnosis and treatment of paediatric inflammatory multisystem syndrome}

Pediatric inflammatory multisystem syndrome (PIMS) is a rare complication of SARS-CoV-2 infection in children. PIMS is a severe condition, involving two or more organ systems. The symptoms overlap with Kawasaki disease, toxic shock syndrome and macrophage activation syndrome. PIMS patients should be treated in an intensive care unit or in an institution with an intensive care background, where cardiological care is also provided. The required specific immunotherapy depends on the clinical presentation. In this paper, after reviewing the relevant international literature, the authors make a recommendation for the diagnostic and therapeutic algorithm for PIMS.

Keywords: paediatric inflammatory multisystem syndrome (PIMS), multiple organ inflammation, diagnosis, treatment

Constantin T, Andrási N, Ponyi A, Goschler Á, Ablonczy L, Kincs J, Csóka M, Egyed B, Horváth Zs, Kalocsai K, Káposzta R, Kardics K, Kemény V, Mosdósi B, Pék T, Szabó Zs, Tóth A, Tory K, Tölgyesi A, Ónozó B, Vágó H, Vilmányi Cs, Weiser P, Szekanecz Z, Kovács G, Szabó A. [Diagnosis and treatment of paediatric inflammatory multisystem syndrome]. Orv Hetil. 2021; 162(17): 652-667.

(Beérkezett: 2021. február 26.; elfogadva: 2021. március 22.) 


\section{Rövidítések}

$\mathrm{ACR}=($ American College of Rheumatology $)$ Amerikai Reumatológusok Kollégiuma; BNP = B-típusú natriureticus peptid; $\mathrm{CDC}=($ Centers for Disease Control and Prevention $)$ Jár ványügyi és Betegségmegelőzési Központ (Egyesült Államok); $\mathrm{CMR}=$ cardiovascularis mágneses rezonancia COVID $=\left(\mathrm{CO}^{-}\right.$ ronavirus disease) koronavírus-betegség; CRP = C-reaktív protein; $\mathrm{CT}=$ (computed tomography) számítógépes tomográfia; $\mathrm{EF}=$ ejekciós frakció; $\mathrm{EKG}$ = elektrokardiográfia; hsTn = (high-sensitivity troponin) magas szenzitivitású troponin; IBD $=$ (inflammatory bowel disease) gyulladásos bélbetegség; Ig = immunglobulin; IL = interleukin; INR = (international normalized ratio) nemzetközi normalizált ráta; iv. = intravénás; IVIG = intravénás immunglobulin; LGE = (late gadolinium enhancement) késői gadolíniumhalmozás; LMWH $=$ (low-molecularweight heparin) kis molekulatömegü heparin; MIS-C = (multisystem inflammatory syndrome in children) gyermekkori multiszisztémás inflammatiós szindróma; MRI = (magnetic resonance imaging) mágnesesrezonancia-képalkotás; NLPR3 = (NLR family pyrin domain containing 3 ) NLR-család pirindomén-3; NLR = (nucleotide-binding oligomerization domain [NOD]-like receptor) nukleotidkötó oligomerizációs domén (NOD)-szerü receptor; $\mathrm{PCR}=$ (polymerase chain reaction $)$ polimeráz-láncreakció; PIMS = (paediatric inflammatory multisystem syndrome) gyermekkori sokszervi gyulladásos szindróma; $\mathrm{RBD}=$ (receptor-binding domain) receptorkötő domén; RNS = ribonukleinsav; SARS-CoV-2 $=$ (severe acute respiratory syndrome coronavirus 2) súlyos akut légúti tünetegyüttest okozó koronavírus- 2 ; sc. $=$ subcutan; $\mathrm{SLE}=$ (systemic lupus erythematosus) szisztémás lupus erythematosus; TNF $\alpha=$ tumornekrózisfaktor-alfa; WHO = (World Health Organization $)$ Egészségügyi Világszervezet

A sokszervi gyulladás a gyermekkori SARS-CoV-2-fertőzés nagyon ritka, de súlyos szövődménye. Kawasaki-betegségre emlékeztető tünetekkel vagy szepszisre, toxikus sokk szindrómára hasonlító állapottal indulhat. Fontos tudni, hogy az előbbiekhez képest gyakoriak és félrevezetőek lehetnek a hasi tünetek: a gastroenteritis vagy akár az akut appendicitis tüneteit is utánozhatják. Éppen ezért egyéb eltérések megléte esetén (magas láz, extrém gyulladásos értékek a laboratóriumi eredményekben, illetve egyéb, nem hasi tünetek) gondolni kell a sokszervi gyulladásra is.

Nem ismertek a hajlamosító tényezők, a COVID-dal ellentétben itt nem figyelhető meg, hogy egyéb társbetegséghez, krónikus betegséghez csatlakozna a súlyos(abb) kórlefolyás. A tüneteket egy - a fertőzést követő - immunreakció okozza úgy, hogy a betegek többnyire már nem fertőznek, PCR-vizsgálatuk is általában negatív. A korábbi vírusinfekciót azonban szerológiai vizsgálattal igazolhatjuk. Mivel a gyermekek esetében sokszor tünetmentesen zajlik a SARS-CoV-2-fertőzés, pusztán a negatív kórelőzmény alapján nem vethető el a betegség lehetősége. Kiemelten fontos az anamnézisben a gyermek környezetében előfordult SARS-CoV-2-infekcióra történő rákérdezés.
A gyerekek többsége jól és prompt reagál az intravénás immunglobulinnal (IVIG) és a glükokortikoiddal folytatott terápiára. Standard terápiaként rezisztens esetekben célzott citokinellenes kezelést alkalmazhatunk.

Nem ismertek egyelőre a betegség kései szövődményei, ezért a betegségen átesett gyermekek szoros követése javasolt.

\section{Módszerek}

Az előkészítő munka során az Amerikai Reumatológusok Kollégiumának (American College of Rheumatology - ACR), az Egyesült Királyság nemzeti konszenzuspaneljének és az Európai Gyermekgyógyászati Akadémiának (European Academy of Pediatrics) az iránymutatásait foglaltuk egységes dokumentumba [1-4]. Ezt követően videókonferencián tárgyalta meg az egyes ajánlásokat a Semmelweis Egyetem I. és II. Gyermekgyógyászati Klinikájának, a Gottsegen György Országos Kardiológiai Intézetnek és a Magyar Reumatológusok Egyesülete Gyermekreumatológia Szekciójának a COVID-munkacsoportja. A szakmaközi egyeztetéseken külön tárgyaltuk a kardiológiai, az infektológiai és a laboratóriumi ajánlásokat. A szakmaspecifikus ajánlások és kiegészítések megfogalmazása során azt tekintettük konszenzusnak, ha az adott szakma valamennyi jelen lévő tagja egyetértett a megfogalmazással. Az egyes nemzetközi ajánlásokat szó szerinti fordításban közöljük, a forrás megjelölésével. Munkacsoportunk ettől eltérő javaslatait mindenhol jelöltük.

\section{Esetdefiníciók}

A releváns nemzetközi irodalomban több esetdefiníció ismert (1. táblázat), nem áll azonban rendelkezésre olyan összehasonlító vizsgálat, amely alapján különbséget tehetnénk a pontosságuk és az alkalmazhatóságuk szempontjából.

\section{Elnevezés}

Az Amerikai Egyesült Államokban a multisystem inflammatory syndrome in children (MIS-C), az Európai Unióban a paediatric inflammatory multisystem syndrome (PIMS) elnevezés terjedt el. Bár az elnevezés nem csak szemantikai kérdés, mi az ajánlásban egységesen a PIMS (gyermekkori sokszervi gyulladásos szindróma) elnevezést alkalmazzuk.

\section{Tünetek}

A PIMS kritériumtünete a tartós, magas láz. A bőrtünetek a Kawasaki-betegségben tapasztalt mucocutan tünetekhez hasonlítanak (elnyomható, apró elemú kiütés, cheilitis, epernyelv). Száraz, nem suppurativ kétoldali 
1. táblázat | Esetdefiníciók a gyermekkori koronavírus-fertőzést követő sokszervi gyulladáshoz (PIMS)

\begin{tabular}{|c|c|c|}
\hline World Health Organization & $\begin{array}{l}\text { Royal College of Paediatrics and Child Health } \\
\text { (Egyesült Királyság) }\end{array}$ & $\begin{array}{l}\text { Centers for Disease Control and Prevention } \\
\text { (Egyesült Államok) }\end{array}$ \\
\hline $\begin{array}{l}\text { Azon gyermekek és serdülők (0-19 év), } \\
\text { akiknél több mint } 3 \text { napos láz áll fenn, } \\
\text { és az alábbiak közül } 2 \text { kritérium teljesül: } \\
\text { • Kiütés vagy nem gennyes kétoldali } \\
\text { conjunctivitis vagy mucocutan gyulladás } \\
\text { jelei (szájon, kézen vagy lábfejen) } \\
\text { - Hipotenzió vagy sokk } \\
\text { - Myocardialis diszfunkció jelei, pericarditis, } \\
\text { valvulitis vagy coronariaeltérés (beleértve az } \\
\text { ECHO-n látott eltéréseket vagy emelkedett } \\
\text { troponin/NT-proBNP értékeket) } \\
\text { - Coagulopathia igazolása (TI, APTI, } \\
\text { emelkedett D-dimer alapján) } \\
\text { - Akut gastrointestinalis tünetek/panaszok } \\
\text { (hasmenés, hányás vagy hasi fájdalom) } \\
\text { ÉS } \\
\text { emelkedett gyulladásos értékek, mint CRP, } \\
\text { süllyedés vagy prokalcitonin } \\
\text { ÉS } \\
\text { egyéb egyértelmú, más mikrobiális eredetú } \\
\text { gyulladás hiánya, beleértve a bakteriális } \\
\text { szepszist és a staphylococcus vagy streptococ- } \\
\text { cusok által kiváltott toxikus sokk szindrómát } \\
\text { ÉS } \\
\text { a SARS-CoV-2-fertózés bizonyítható } \\
\text { (RT-PCR, antigénteszt vagy pozitív szerológi- } \\
\text { ai eredmény), vagy valószínú kontaktus } \\
\text { SARS-CoV-2-fertőzöttel. } \\
\text { Gondolni kell ezen szindrómára komplett és } \\
\text { inkomplett Kawasaki-betegség és a toxikus } \\
\text { sokk szindróma tüneteinél. }\end{array}$ & $\begin{array}{l}\text { Gyermek tartós lázzal, gyulladás (neutrophi- } \\
\text { lia, emelkedett CRP és lymphopenia) és egy } \\
\text { vagy többszervi elégtelenség jeleivel (sokk, } \\
\text { kardiológiai, légzószervi, vese, gastrointestina- } \\
\text { lis vagy neurológiai eltérés), valamint az alábbi } \\
\text { jellegzetességekkel: lásd RCPCH-esetdefiní- } \\
\text { ció. } \\
\text { Beleértve azon gyermekeket, akik a Kawasaki- } \\
\text { betegség kritériumait részben vagy teljesen } \\
\text { teljesítik. (a) } \\
\text { Egyéb, mikrobától eredő kórok kizárása } \\
\text { esetén, beleértve a bakteriális szepszist, a } \\
\text { staphylococcus vagy streptococcusok által } \\
\text { kiváltott toxikus sokk szindrómákat és az } \\
\text { infektív eredetú myocarditiseket (például } \\
\text { enterovírus-fertőzés). } \\
\text { Gyanú esetén szakemberrel való konzultáció } \\
\text { még a fenti összes vizsgálati eredmény } \\
\text { megérkezése előtt ajánlott. } \\
\text { A SARS-CoV-2-PCR eredménye lehet negatív } \\
\text { és pozitív is. } \\
\text { (a) A Kawasaki-betegség kritériuma tartós láz } \\
\text { és } 4-5 \text { a következő, jellemző tünetekből: } \\
\text { ajakpirosság vagy cserepes ajkak, epernyelv és/ } \\
\text { vagy vérbő szájnyálkahártya vagy pharynx; } \\
\text { kétoldali conjuctivalis belövelltség, exsudatum } \\
\text { nélkül; kiütés (maculopapularis, diffúz } \\
\text { erythroderma); tenyéri és talpi oedema, } \\
\text { pirosság és/vagy hámlás a körmök körül; } \\
\text { nyaki nyirokcsomó-megnagyobbodás. }\end{array}$ & $\begin{array}{l}\text { Azon } 21 \text { év alatti, lázas beteg, akinek } \\
\text { laboratóriumi vizsgálati eredményeiben } \\
\text { gyulladás jelei észlelhetók, és súlyos, kórházi } \\
\text { ellátást igénylö tünetei vannak többszervi (>2) } \\
\text { elégtelenséggel (keringési, vese, légzőszervi, } \\
\text { gastrointestinalis, hematológiai, bőr vagy } \\
\text { neurológiai). } \\
\text { Láz: >38,0 }{ }^{\circ} \text { C, vagy a láz szubjektív tünetei } \\
\text { állnak fenn } \geq 24 \text { órája. } \\
\text { A laboratóriumi eredményekben az alábbiak } \\
\text { közül l vagy több jellemzó, egyebek mellett: } \\
\text { emelkedett CRP, süllyedés, fibrinogén, } \\
\text { prokalcitonin, ferritin, LDH, D-dimer vagy } \\
\text { IL6; emelkedett neutrophilszám; csökkent } \\
\text { lymphocytaszám; és alacsony albuminszint } \\
\text { ÉS } \\
\text { nincs más lehetséges kórok } \\
\text { ÉS } \\
\text { igazolt vagy igazolt, nemrég átvészelt } \\
\text { SARS-CoV-2-fertőzés az alábbi módszerek } \\
\text { egyikével: RT-PCR, szerológia vagy antigén- } \\
\text { teszt, vagy SARS-CoV-2-fertőzöttel kontaktus } \\
\text { a tünetek megjelenése előtti } 4 \text { hétben. } \\
\text { Kiegészítő megjegyzés: } \\
\text { néhány beteg kimerítheti a komplett vagy } \\
\text { inkomplett Kawasaki-betegség diagnózisát, de } \\
\text { jelentendő, ha teljesíti a MIS-C esetdefiníció- } \\
\text { ját. } \\
\text { Minden, SARS-CoV-2 miatt elhunyt gyermek } \\
\text { esetén gondolni kell MIS-C-re. }\end{array}$ \\
\hline
\end{tabular}

APTI = aktivált parciális tromboplasztinidő; $\mathrm{CRP}=\mathrm{C}$-reaktív protein; $\mathrm{ECHO}=$ echokardiográfia $; \mathrm{IL}=$ interleukin; $\mathrm{LDH}=$ laktátdehidrogenáz; MIS-C = gyermekkori multiszisztémás inflammatiós szindróma; NT-proBNP = N-terminális pro-B-típusú natriureticus peptid; PI = protrombinidő; PIMS = gyermekkori sokszervi gyulladásos szindróma; $\mathrm{RCPCH}=($ Royal College of Paediatrics and Child Health $)$ Királyi Gyermekgyógyászati és Gyermekegészségügyi Főiskola (London); RT-PCR = reverztranszkripciós polimeráz-láncreakció; SARS-CoV-2 = súlyos akut légúti tünetegyüttest okozó koronavírus-2; TI = thrombinidő

conjunctivitist láthatunk, amely a limbus területére nem terjed rá. A nyaki lymphadenopathián túl egyéb organomegalia nem jellemző. A kéz és a láb hyperaemiás, oedemás lehet. A betegek általános állapota elesett, gyenge. A betegek egy másik részében diszkrét vagy hiányzó bőrtünetek mellett dominálnak a keringési elégtelenség jelei. A PIMS jellemző tünete a hasfájás, a hasmenés, a hányinger, a hányás. A hasi tünetek akut gastroenteritisre vagy akut appendicitisre hasonlíthatnak. Tudatzavar, nyak- és tarkótáji fájdalom, sőt meningealis izgalmi jelek is előfordulhatnak. A tünetek megoszlását az 1 . ábrán foglaltuk össze.

A laboratórumi vizsgálatok során a vérképben anaemiát, leukocytosist, neutrophiliát és lymphocytopeniát észlelhetünk. Jellemző a relatív thrombopenia. Érdekes módon a nagyon magas CRP-szint mellett a ferritinszint csak mérsékelten emelkedik.

A differenciáldiagnosztika során kizárandó legfontosabb kórállapotokat a 2. táblázat részletezi.

\section{PIMS és Kawasaki-kór}

A SARS-CoV-2-től független, a Kawasaki-betegségben szenvedő betegekre a SARS-CoV-2-világjárvány idején továbbra is számítanunk kell.

A PIMS számos epidemiológiai, klinikai és laboratóriumi jellemzője eltérhet a SARS-CoV-2-től független Kawasaki-betegségtől [2]:

- Az afrikai, afrokaribi származású és spanyol ajkú betegek között nagyobb a PIMS előfordulási gyakorisága, a kelet-ázsiai származásúak körében viszont alacsonyabb [2].

- A PIMS-ben szenvedő betegek szélesebb korosztályt ölelnek fel. Míg a Kawasaki-betegség jellemzően a kisdedek betegsége, a PIMS inkább érinti a 9-14 éves korosztályt (kisebb számban valamennyi korosztályban jelentkezhet) [2].

- A PIMS-betegek körében gyakoribbak a gastrointestinalis és a neurológiai tünetek, és sokkal nagyobb 


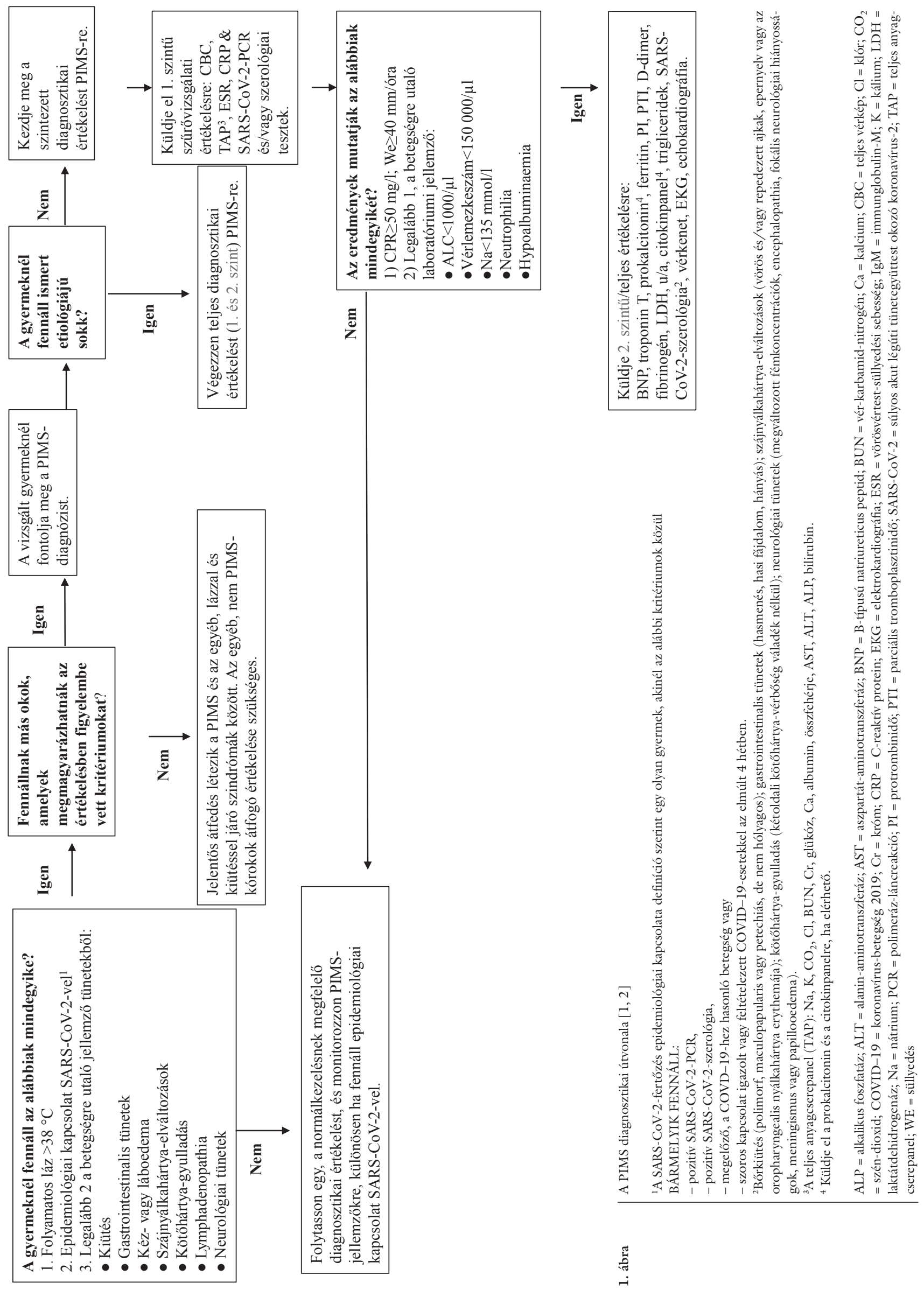




\begin{tabular}{|c|c|}
\hline Differenciáldiagnózis & Klinikai kép \\
\hline Bakteriális fertőzés/szepszis & $\begin{array}{l}\text { - A gyermek általános állapota rossz. } \\
\text { - Vitális paraméterekben eltérés, jelei vannak a rossz perfúziónak, tudatzavar van jelen. } \\
\text { - Keresni kell a fertőzés fókuszát; bőr/lágyrész, meningitisre, pneumoniára utaló jeleket. } \\
\text { - A megfelelő mikrobiológiai mintavételek (hemokultúra, liquor stb.) történjenek meg. }\end{array}$ \\
\hline Toxikus sokk szindróma & $\begin{array}{l}\text { - A tünetek és klinikai jelek gyorsan alakulnak ki. } \\
\text { - A fertôzés forrása klinikailag nem mindig azonosítható egyértelmüen (staphylococcus kiváltotta TSS); } \\
\text { értékelendő a menstruációhoz kötött, valamint az a nélkül jelentkezó kórállapot. } \\
\text { - Megjelenés: } \\
\text { - láz/hidegrázás; } \\
\text { - hipotenzió; } \\
\text { - diffúz erythemoid kiütés; } \\
\text { - lehet többszervi érintettség, beleértve: hasmenés, hepatitis és akut veseelégtelenség. }\end{array}$ \\
\hline $\begin{array}{l}\text { Staphylococcus okozta } \\
\text { „leforrázott bőr" szindróma } \\
\text { (SSSS) }\end{array}$ & $\begin{array}{l}\text { - Gyakori } 6 \text { év alatti gyermekekben: } \\
\text { ○ jelentős bőrfájdalom, és a hajlatok bőre erythemás; } \\
\text { ○ a bőr generalizált erythemája alakul ki, ahogy a tünetek progrediálnak; } \\
\text { ○ a dörzsölésnek kitett területeken nem feszülő bullák erosióval; } \\
\text { ○ láz, irritabilitás, rossz általános állapot. }\end{array}$ \\
\hline Kawasaki-betegség & $\begin{array}{l}\text { - Általában a } 6 \text { év alatti gyermekekben jelentkezik, számos klinikai jellegzetesség közös a PIMS-szel: } \\
\text { ○ láz és irritabilitás; } \\
\text { ○ kiütés; } \\
\text { ○ nem purulens conjuctivitis; } \\
\text { ○ nyaki nyirokcsomó-megnagyobbodás; } \\
\text { ○ végtagi eltérések, mint az oedema. }\end{array}$ \\
\hline Rickettsiosisok & $\begin{array}{l}\text { - Tavasszal és nyáron jellemzó (kullancs által terjesztett betegségek). } \\
\text { - RMSF: láz, fejfájás, melyet kiütés követ (maculák, petechiák, melyek bokán/csuklón indulnak, majd } \\
\text { továbbterjednek a törzsre, tenyérre, talpra, lábfejre; 10-20\%-ban nincs kiütés), a laboratóriumi eredmények- } \\
\text { ben thrombocytopenia, hyponatraemia. } \\
\text { - Ehrlichia/anaplasma: láz, fejfájás, kiütés; jellemző laboratóriumi eltérések a leukopenia vagy a thrombocy- } \\
\text { topenia. }\end{array}$ \\
\hline Vírusfertőzések & $\begin{array}{l}\text { - A nem típusos megjelenésű PIMS-betegek vírusfertőzés tüneteit mutathatják, gondolni kell a következókre: } \\
\text { - adenovírus; } \\
\text { - enterovírus (általában nyáron); } \\
\text { - EBV; } \\
\text { - HHV6 (csecsemók, kisdedek). }\end{array}$ \\
\hline Myocarditis & $\begin{array}{l}\text { - Kardiogén sokk klinikai tünetei (hideg végtagok, elnyomható pulzus, megnyúlt CRT, hipotenzió). } \\
\text { - Emelkedett troponinérték. } \\
\text { - ST-eltérés lehet az EKG-n. } \\
\text { - Balkamra-diszfunkció lehet az ECHO-n. } \\
\text { - Gyakran jelentkezik arrhythmia. }\end{array}$ \\
\hline Szérumbetegség & $\begin{array}{l}\text { - Általában gyógyszeres kezelést vagy más terápiát követően jelentkezik: } \\
\text { - láz; } \\
\text { - kiütés; } \\
\text { - ízületi fájdalom. }\end{array}$ \\
\hline
\end{tabular}

EBV = Epstein-Barr-vírus; ECHO = echokardiográfia $;$ EKG = elektrokardiográfia; CRT = kapilláris-újratelődési idő; HHV = humán herpeszvírus; PIMS = gyermekkori sokszervi gyulladásos szindróma; RMSF = (Rocky Mountain spotted fever) sziklás-hegységi foltos láz; SSSS = staphylococcus okozta „leforrázott bőr” szindróma; TSS = toxikus sokk szindróma

valószínúséggel mutatnak szívmüködési zavart (ritmuszavarok és kamrai diszfunkció), mint a SARSCoV-2-től független Kawasaki-betegségben szenvedő gyermekek [2].

- A betegség indulásakor a PIMS-ben szenvedő betegek esetében alacsonyabb a vérlemezkeszám (legyünk figyelemmel a relatív thrombopeniára is), alacsonyabb a lymphocyták abszolút száma, és magasabb a CRPszint, mint a SARS-CoV-2-től független Kawasaki-betegségben szenvedő betegek körében [2].
A PIMS epidemiológiai vizsgálatai arra mutatnak, hogy a fiatalabb gyermekekben nagyobb valószínúséggel jelentkeznek Kawasaki-betegség-szerü jellemzők, míg az idősebb gyermekeknél nagyobb valószínúséggel alakul ki szívizomgyulladás és sokk [2]. Kawasaki-sokkszindrómában, bár alacsony vérnyomással jár, csak az esetek egyharmadában látunk balkamrafunkció-zavart [5, 6], ez az arány PIMS-ben 60\% [7]. Itt jegyezzük meg, hogy bár felnóttkorban az akut myocarditis a SARS-CoV-2-fertőzés gyakori velejárója $[8,9]$, a PIMS- 
ben észlelhető mycardiumérintettség patológiája eltérő, két külön betegségről (esetleg súlyosságról) van szó. Erre utal a PIMS-betegek gyors reagálása az alkalmazott kezelésre, a systolés diszfunkció gyors rendeződése és a csak enyhén vagy mérsékelten emelkedett troponinértékek [10].

Nem ismert, hogy PIMS-ben a szívkoszorúér-aneurysma előfordulása eltér-e a SARS-CoV-2-tôl független Kawasaki-betegségben tapasztalhatóktól; az utánkövetési szabályok szempontjából azonban fontos tény, hogy a Kawasaki-betegségre jellemző tüneteket nem mutató PIMS-betegekben is kialakulhat szívkoszorúér-aneurysma $[2,11]$

\section{Kimenetel}

A PIMS halálozása $1,7-1,8 \%[7,12]$, ami bár alacsonynak mondható, mégis magasabb, mint a koronavírus-fertőzés gyermekkori mortalitása, ami 0,09\%-nak bizonyult [13]. A szövődmények között kell megemlíteni az előbb már említett koszorúér-tágulatot [11], illetve az akut myocarditis következtében kialakuló, hegesedés okozta ritmuszavarokat. Cardiomyopathia kialakulását egyelőre nem észlelték.

\section{Ajánlások}

\section{Diagnosztika}

\section{Laboratóriumi vizsgálatok}

A gyermek PIMS-gyanú miatt történő kivizsgálása során szükséges laboratóriumi vizsgálatokat a 3. táblázatban foglaljuk össze.

A PIMS súlyossága széles skálán mozog, ismertek enyhébb esetek is. Az ACR ezért előzetes szürést javasol azon betegek esetében, akiknél egyértelmü kapcsolat igazolható a SARS-CoV-2-fertőzéssel (pozitív szerológia vagy PCR vagy szoros kontakt status a tüneteket megelőző 4 hétben), és a PIMS klinikai tüneteit mutatják: szúró jellegú laboratóriumi vizsgálati panelt javasolnak [1] (1. ábra). Magas gyulladásos aktivitás és legalább egy további laboratóriumi tünet (lymphopenia, neutrophilia, thrombocytopenia, hyponatraemia, hypoalbuminaemia) megléte esetén javasolják a kiterjesztett laboratóriumi vizsgálati panelt.

A munkacsoport felhívja a figyelmet, hogy a gyermekek állapota gyorsan romolhat, ezért a stratifikált laboratóriumi megközelítés csak vitálisan stabil beteg esetében alkalmazható. Rossz általános állapot, kóros vitális paraméterek esetén a teljes vizsgálati sort javasolt elindítani rögtön a felvétel pillanatában.

A javaslatban szerepel a citokinek vizsgálata (az IL6, az IL10 és a TNF $\alpha$ szintjében várhatunk emelkedést), ez azonban a munkacsoport véleménye szerint nem tartozik a „minimum standard of care” kategóriájába, a kezelés indikációjának felállítása és a terápia monitorozása ezen laborparaméterek ismerete nélkül is végezhető.
3. táblázat | PIMS gyanúja esetén elvégzendő vizsgálatok [4]

\begin{tabular}{ll}
\hline A kivizsgálás menetének listája PIMS-betegekben \\
\hline Vérvizsgálatok & Vérgáz, laktáttal \\
& Teljes vérkép \\
& Vesefunkciós vizsgálatok \\
& Májfunkciós vizsgálatok (LDH, CK, triglicerid) \\
& Amiláz, amennyiben van hasi panasz \\
& CRP, PCT, ferritin, süllyedés \\
& Alvadási paraméterek (D-dimer és fibrinogén is) \\
& Troponin \\
& pro-BNP \\
& D-vitamin \\
\hline Képalkotó & EKG \\
vizsgálatok & Mellkasröntgen \\
& ECHO \\
& Hasi ultrahangvizsgálat - ha van hasi panasz \\
\hline Mikrobiológiai & Hemokultúra \\
& Vizeletleoltás \\
& Garatleoltás \\
& Nasopharyngealis légúti PCR \\
& Mycoplasma pneumoniae szerológia \\
& ASO \\
& Baktérium-PCR-vizsgálatok, például: meningo- \\
& coccus, staphylococcus, pneumococcus, \\
& streptococcus (vérből) \\
& Vírus-PCR-vizsgálatok: adeno-, EBV, CMV, \\
& parvo-, entero-, parechovírus (vérböl) \\
& HIV \\
\hline Légúti PCR \\
Széklet- és szérum-PCR megfontolandó \\
Szerológia \\
& \\
& \\
& \\
& \\
& \\
&
\end{tabular}

ASO = anti-sztreptolizin $\mathrm{O}$; CK = citokeratin; CMV = cytomegalovirus; $\mathrm{CRP}=\mathrm{C}$-reaktív protein; $\mathrm{EBV}=$ Epstein-Barr-vírus; $\mathrm{ECHO}=$ echokardiográfia; EKG = elektrokardiográfia; HIV = humán immundeficientiavirus; $\mathrm{LDH}$ = laktátdehidrogenáz; PCR = polimeráz-láncreakció; PCT $=$ prokalcitonin; PIMS = gyermekkori sokszervi gyulladásos szindróma; pro-BNP = pro-B-típusú natriureticus peptid; SARSCoV-2 = súlyos akut légúti tünetegyüttest okozó koronavírus-2

Természetesen további diagnosztikai vizsgálatokra lehet szükség, beleértve - de nem kizárólag - a mellkasi, a hasi és/vagy a központi idegrendszeri képalkotó eljárások alkalmazását és a lumbálpunkciót [2].

\section{A SARS-CoV-2 vizsgálata}

A betegek döntő többségében a SARS-CoV-2-szerológia pozitív, míg az esetek körülbelül negyedében a PCR is pozitív.

A SARS-CoV-2-fertőzés vizsgálata során javasolt légúti PCR-vizsgálatot, antitest-szerológiai vizsgálatot végezni. Nem javasoltak az antigénkimutatáson alapuló diagnosztikus tesztek.

Munkacsoportunk felhívja a figyelmet, hogy a tüskefehérje- (spike protein) ellenes ellenanyag vizsgálatán alapuló releváns szerológiai vizsgálat javasolt.

Vannak esetek, amikor a PCR, a szerológia és a kontaktkutatás is negatív eredménnyel zárul, vagyis ezen tények alapján a PIMS-t nem szabad kizárni.

A tapasztalatok alapján a PIMS-esetek több héttel később jelentkeztek, mint a COVID-betegek megjelenésé- 
nek csúcsa [14]. Az időbeli eltolódás általában 3-6 hét $[14,15]$. Ez az időbeli eltolódás magyarázhatja, hogy míg a szerológiai tesztek az esetek 80-90\%-ában, addig a PCR-tesztek az esetek csupán 20-40\%-ában bizonyultak pozitívnak $[11,14,16,17]$.

A lezajlott fertőzések tekintetében a specifikus IgGtesztek általában nagyobb érzékenységgel bírnak, mint az IgM- vagy IgA-tesztek [18]. A specifikus antitestek megjelenésének és időbeli lecsengésének alapján a PIMS laboratóriumi diagnosztikájához érdemes olyan tesztet választani, amely mindhárom ( $\operatorname{IgG}, \operatorname{IgM}, \operatorname{IgA}$ ) izotípust kimutatja. Amennyiben ilyen nem érhető el, akkor javasolt a specifikus IgG kimutatása (lehetőleg kombinálva IgM-teszttel).

Különböző antigéntartalmú szerológiai tesztek érhetők el: nukleokapszid, tüske (S)-fehérje vagy ezek keverékét tartalmazó tesztek. A COVID szerológiai diagnosztikájában hasonló érzékenység és specificitás érhető el mindhárom esetben. A PIMS esetében kevés a közölt adat, de van olyan forrás, mely szerint PIMS esetében dominánsan az S-fehérje ellen termelődik antitest, a nukleokapszid antigénnel szemben kevésbé [19]. Ezt a kérdést tovább kell vizsgálni, amíg elegendő adat össze nem gyúlik. Addig javasolt olyan teszttel végezni a vizsgálatot, amely tartalmaz tüskefehérje (teljes, S1- vagy ún. RBD-domén) antigént (is).

A kereskedelmi forgalomban lévő SARS-CoV-2 laboratóriumi tesztek gyorsan változnak. Újabban elérhetők kvantitatív meghatározásra alkalmas tesztek. A szakirodalomban található arra vonatkozó adat, hogy a szerológiai tesztek kvantitatív eredménye diagnosztikus értékú, mert például szignifikánsan magasabb értéket találtak PIMS-diagnózist kapó gyermekek esetében, mint COVID-ban szenvedő gyermekeknél [20]. Lehetőség szerint javasolt kvantitatív eredményt nyújtó teszt végzése, amennyiben erre nincs lehetőség, akkor legalább szemikvantitatív eljárást javasolt használni.

Várható, hogy a WHO SARS-CoV-2 standard preparátumot fog elérhetóvé tenni, melynek segítségével a tesztek standardizálhatók lesznek. Ez további előrelépést jelenthet a jövőben.

\section{Fertőzőképes-e a PCR-pozitív,} magas ellenanyagtiterrel rendelkező gyermek?

A SARS-CoV-2 légúti mintából történő kimutatása és a fertőzőképesség közötti összefüggés jelenleg sem a felnőtt, sem a gyermekpopulációban nem ismert pontosan.

A CDC vizsgálatai alapján a tünetmentes PCR-pozitív személyek esetén a vírusátvitel kockázata a mintavétel 7. napjától egyenértékű a 14. napi vírusátviteli kockázattal [21]; ezen eredményeknek köszönhetően csökkent a járványügyi elkülönítés időtartama 14 napról 10 napra.

Egy nagy, kontaktkutatást végző vizsgálatban nem igazoltak egyetlen fertőzést sem a közös háztartásban élő és a kórházi szoros kontaktok között, ha expozíciójuk 6 nappal az indexpáciens első tüneteinek megjelenését követően történt [22].
Az elhúzódó PCR-pozitivitás előfordulása az életkorral és a betegség súlyosságával együtt növekszik, a hospitalizált betegeken a 34 napot is elérheti [23]. Az elhúzódó PCR-pozitivitás azonban nem egyenértékú az elhúzódó fertőzőképességgel: ugyanezen vizsgálatban a vírustenyészetben 7 napig volt kimutatható élő vírus a betegekből [23]. A PCR-pozitivitás egyes esetekben 12 hétig is fennmaradhat $[24,25]$.

Gyermekek esetében a tünetmentes PCR-pozitivitás, különböző kohorszokat vizsgálva, a 90\%-ot is elérheti [26]. A vírus-RNS-kimutatás időtartama gyermekeknél Han és mtsai vizsgálata alapján, tünetmentes esetekben, átlagosan 14 nap, míg alsó és felső légúti tüneteket mutató esetekben átlagosan 18 nap [27].

A SARS-CoV-2-re adott ellenanyagválasz kinetikájáról felnőtt populációban végzett vizsgálatok alapján vannak ismereteink. A tüskefehérje elleni ellenanyagok izotípustól függetlenül a tünetek megjelenését követő 5-14 naptól kezdődően meredeken emelkednek. Az IgM-ellenanyagok már az 5. napon megjelenhetnek, míg az IgG a legkorábban a 11. naptól detektálható [28]. Az IgM- és IgA-ellenanyagok hamarabb érik el csúcspontjukat, míg az IgG-típusú ellenanyagok a tünetek megjelenését követő 25. napon érték el a legmagasabb koncentrációt. Míg az IgM- és IgA-ellenanyagok csökkennek 4 hét múlva, addig az IgG-ellenanyagok a 28. nap után is magas szinten maradnak, és jól korrelálnak a projektivitással [29].

Mindezek alapján PCR-pozitív és magas SARSCoV-2- (tüskefehérje elleni) ellenanyagszinttel rendelkező gyermek esetén csak következtetni tudunk a betegség kezdetére és ebből a fertőzőképesség hosszára, de egyértelmú állásfoglalást nehéz tenni. Magas IgG-szint a 14. naptól valószínű, ezért a beteget ebben az időpontban a PCR-pozitivitás ellenére (tünetektől függően) már nagy biztonsággal (>99\% valószínúséggel) nem fertőzőnek lehet minősíteni [28].

\section{Egyéb fertőzések kizárása}

A fertőző betegségek közül a PIMS-hez hasonló tüneteket okozhat az influenza, az enterovírus, az adenovírus, hasmenés esetén gondoljunk a rotavírus vagy a calicivírus lehetőségére. A virológiai vizsgálatok mellett a „,bakteriológiai screening” szintén szülkséges a helyi protokolloknak megfelelően (hemokultúra, hasmenés esetén székletleoltás). Infektológiai javaslatra szülkséges lehet Yersinia- és Leptospira-szerológiai vizsgálat. Az egyéb fertőző betegségek kizárása közben gondoljunk a toxikus sokk szindróma lehetőségére.

A szükséges vizsgálatokat az 3. táblázat részletezi.

\section{Infektológiai konzílium}

A pontos differenciáldiagnosztika érdekében munkacsoportunk infektológiai konzíliumot javasol a felvételt követő 24 órán belül. 


\section{Az ellátás szintjei}

\section{Ambuláns ellátás}

A PIMS járóbetegszintü (vagyis ambuláns) ellátása megfelelő lehet a jó állapotban lévő, stabil életjelekkel és megnyugtató fizikális statussal (nem teljesíti a Kawasakibetegség kritériumait, bőrkiütésen kívül nyálkahártyatünet nem észlelhető, és a szisztémás gyulladás mellett nincs szervi károsodásra utaló jel) bíró gyermekeknél abban az esetben, ha a szoros klinikai utánkövetés biztosított [2].

\section{Kórházi ellátás}

A PIMS miatt vizsgált betegek további vizsgálatok céljából történő kórházi felvétele javasolt, ha a következő tüneteket észleljük [2]:

- rendellenes életjelek (tachycardia, tachypnoe),

- bármilyen súlyosságú légzési zavar,

- neurológiai tünetek vagy a mentális állapot megváltozása (beleértve a finom klinikai tüneteket is),

- akár csak enyhe fokú vese- vagy májkárosodásra utaló jelek,

- jelentősen megemelkedett gyulladásos markerek (C-reaktív fehérje $\geq 100,00 \mathrm{mg} / \mathrm{l}$ ),

- rendellenes EKG, a B-típusú natriureticus peptid (BNP) vagy a troponin $\mathrm{T}$ emelkedett szintjei.

Sokk, légzési zavar, neurológiai tünetek (megváltozott mentális állapot, encephalopathia, fokális neurológiai hiánytünetek, meningismus, papillooedema), dehidráció vagy a Kawasaki-betegségre jellemző tünetek esetén a beteg kórházi felvétele szülkséges a normálellátásnak megfelelően, a beteg PIMS-statusától függetlenül [2].

A PIMS-szel kórházba felvett gyermekeket multidiszciplináris csoportnak kell kezelnie, amely tartalmaz: sürgősségi orvostanban, intenzív terápiában jártas gyermekgyógyászt, gyermek intenzív terápiás szakorvost, infektológust, kardiológust, gyermekreumatológust és hematológust. A klinikai tünetektől függően, egyéb szakterületek képviselőivel történő konzultáció is szükségessé válhat; ezen szakterületek lehetnek, de nem kizárólagosan: gyermekneurológia, -nefrológia, -hepatológia és-gasztroenterológia [2].

\section{PIMS-ben szenvedő gyermek kardiológiai vizsgálata} és kezelése

\section{Laboratóriumi vizsgálatok}

A diagnózis felállításakor PIMS-ben szenvedő, valamint kóros BNP- és/vagy troponin T-szinttel rendelkező betegeknél ezeket a laboratóriumi paramétereket nyomon kell követni, amíg azok nem normalizálódnak [2].

A jelentősen megemelkedett BNP-szint segíthet azonosítani a balkamra-diszfunkcióval bíró betegeket. A BNP akutfázis-fehérjeként is múködik, enyhe emelkedésére számíthatunk jó myocardialis funkció mellett szepszisben, pneumoniában is [30].

A legtöbb adat a felnőttek vizsgálata során született, de általánosan elfogadott, hogy a cardialis troponin (tro- ponin I és T) értékei a legszenzitívebb mutatók a myocyták bántalmának kimutatására myocarditisben, a többi konvencionális nekroenzimmel összehasonlítva [31]. Normálértéket meghaladó troponinértékeket kaphatunk jelentősebb fizikai megterhelést követően, azonban $\geq 20 \%$-os emelkedés a troponinszintekben a myocardialis nekrózis kimondására diagnosztikus [32]. Tapasztalataink alapján a magas szenzitivitású troponin I (hsTnI) specificitása alacsonyabb, ezért a hsTnT vizsgálatát javasoljuk.

\section{$E K G$}

Legalább 48 óránként EKG-t kell végezni a kórházban fekvő PIMS-betegeknél, valamint az utánkövetés során a kontrollvizsgálatoknál. Vezetési rendellenességek fennállása esetén a betegeknél folyamatos telemetriás monitorozást kell alkalmazni a kórházi tartózkodás idejére, az utánkövetésre pedig megfontolandó a Holter-monitor alkalmazása [2].

\section{Echokardiográfia}

A diagnózis felállításakor és a klinikai nyomon követés során készített echokardiogramoknak tartalmazniuk kell a kamrai és billentyúfunkció, a pericardialis folyadékgyülem értékelését és a koszorúérméreteknek a testfelületre vonatkoztatott méréseit z-pontszámok alkalmazásával [2].

Munkacsoportunk véleménye alapján legkésőbb 1224 órán belül javasolt a balkamra-funkció minimum tájékozódó vizsgálata klinikailag instabil betegben.

Teljes körü kardiológiai szív-ultrahangvizsgálat javasolt klinikailag instabil betegben 48 órán belül. Kóros balkamra-funkció esetén ezt követően rendszeres kardiológiai kontrollok javasoltak a normalizálódásig.

Stabil vitális paraméterek esetén legkésőbb az 1. héten javasolt kardiológiai vizsgálat a coronariaátmérők megítélésére.

Az ACR ajánlása alapján az echokardiográfiás vizsgálatokat meg kell ismételni legalább 7-14 naponként és a felvételt követő 4-6. héten [2]; az angol ajánlás szerint klinikailag instabil betegben naponta javasolt ismételni [3].

Munkacsoportunk javaslata alapján kóros balkamrafunkció esetén rendszeres, klinikai állapottól függő sűrüségú kardiológiai kontrollok javasoltak a funkció teljes normalizálódásáig. Normális balkamra-funkció esetén a terápia megkezdése után az 1., a 2. és a 6. héten javasolt részletes echokardiográfiás vizsgálat. A szívkoszorúéraneurysma kialakulásának kockázata nem függ össze a betegség súlyosságával, sem a klinikai prezentációval (vagyis nemcsak a Kawasaki-szerü tünetcsoportra jellemző szövődmény, hanem a sokk típusú PIMS-re és a kevert fenotípusra is), ezért valamennyi beteg esetében javasolt az echokardiográfiás utánkövetés [11].

Az ACR ajánlása alapján azon betegek esetében, akiknél betegségük akut fázisában szívmúködési rendellenességek fordulnak elő, a PIMS-diagnózis után egy évvel 
echokardiogram készítését kell mérlegelni. Bal kamrai diszfunkcióval és/vagy szívkoszorúér-aneurysmával rendelkező betegeknél gyakoribb echokardiogramra lesz szükség [1]. Az angol ajánlás nem foglal állást a kardiológiai követésről stabil PIMS esetén, illetve coronariaérintettség esetén is kardiológiai konzílium kezébe helyezi a további teendőkról való döntést [3].

Munkacsoportunk javaslata, hogy a betegség akut fázisát követően a Kawasaki-betegségben javasolt kardiológiai utánkövetés az irányadó [33]. Coronariaeltérés esetén a Kawasaki-betegségnek megfelelő utánkövetési protokoll javasolt (szükség esetén kardio-CT, angiográfia és/vagy stressz-echokardiográfia). Szerencsére a PIMS-ben leírt coronariaeltérések többsége enyhe fokú tágulat, a „giant” (óriás) aneurysma irodalmi ritkaság (vélhetően - részben - a betegség adekvát kezelésének köszönhetően) [11, 14, 34-37].

\section{Egyéb képalkotó vizsgálatok}

A myocarditis képalkotó diagnosztikájának arany standardja a szíp-MRI (CMR) [38, 39], amely a kamrai volumenek, morfológia és funkció megítélésére alkalmas módszer, és speciális szekvenciák révén alkalmas a szöveti oedema, illetve nekrózis/fibrosis kimutatására is [40]. A gadolíniumalapú kontrasztanyag alkalmazásával készült, késői kontrasztanyag-halmozásos ('late gadolinium enhancement' - LGE-) felvételek alapján elkülöníthető az ischaemiás és a non-ischaemiás etiológiájú myocardialis károsodás. A CMR szenzitivitása magas „infarct-like” (infarktusszerü), alacsonyabb „cardiomyopathy-like" (cardiomyopathia-szerü ) és egészen alacsony arrhythmiaprezentáció esetén [41]. A klinikailag javulást mutató beteg esetében az akut betegséget követően 3 hónappal készített CMR-felvételeken az LGE progressziója növeli a kései cardiovascularis események rizikóját [38]. Korábban Grün és mtsai biopsziával igazolt myocarditises betegek hosszú távú követése alapján a cardiovascularis mortalitás legjobb független rizikófaktorának az LGE-t találta [42]. Gyermekkorban a CMR az akut fázisban alkalmazható szintén a myocarditis megerősítésére, az LGE a kimenetel tekintetében szignifikáns rizikófaktornak adódott [43].

Felnőtt COVID-betegekben jelentkező myocarditis esetén van olyan közlemény, amelyben a betegek számottevő részében észleltek CMR-en kései LGE-t, a betegek 50\%-ában pedig oedemát és cardiomegaliát is [44]. Puntmann és mtsai cardialis panasszal nem bíró, COVID-betegségből nemrég felépült betegeket CMRrel vizsgálva, közel 80\%-ukban találtak zajló myocarditisre utaló eltéréseket [45]. Eredményeik interpretációját azóta többen - köztük a Semmelweis Egyetem Városmajori Klinikájának munkacsoportja is - megkérdőjelezték [46]. Érdekes adat, hogy a patológiai vizsgálatok az esetek 1-7\%-ában találtak akut myocarditist SARS-CoV2-infekciót követő kórboncolás során. A közlemény szerzői azt a következtetést vonták le, hogy míg a SARS-
CoV-2-fertőzésben a szívérintettség gyakorisága igen magas (47,8\%), ennek kis része myocarditis [47].

Az ACR ajánlása alapján CMR-vizsgálat indokolt lehet 2-6 hónappal a PIMS-diagnózis után azoknál a betegeknél, akik jelentős mértékú, átmeneti vagy tartós bal kamrai diszfunkciót mutattak a betegség akut fázisában (bal kamrai ejekciós frakció $[\mathrm{EF}]<50 \%)$. A CMR-nek a szívizom jellemzésére kell összpontosítania, beleértve a funkcionális értékelést, a T1/T2 súlyozott képalkotást, a T1 „mapping " és extracelluláris térfogat-kvantifikációt, valamint az LGE-t [2].

Az angol PIMS-ajánlás érdekes módon nem nyilatkozik a CMR-vizsgálatról, miközben sportorvosaik egy, az amerikainál liberálisabb ajánlást fogalmaztak meg a sportolók MR-vizsgálatával kapcsolatban [3, 48].

A jelen kézirat publikálásának idejében nem ismert a PIMS hosszú távú kimenetele, de feltételezhető, hogy a betegek egy csoportjában fibrosis és hegesedés alakulhat ki [1]. A kemény evidenciák és a gyermekadatok hiányában munkacsoportunk az alábbi javaslatot teszi: a kardiológiai konzílium a betegség akut szakában, a teljes klinikai kép (a balkamrafunkció-zavar súlyossága, ritmuszavar jelenléte) alapján dönt arról, hogy a kezelést követően 3-6 hónappal a részletes cardiovascularis rizikószúrés részeként történjen-e CMR-vizsgálat. A CMR-vizsgálatot „mapping” technikával rendelkező berendezésen javasolt elvégezni. A „mapping” - eddigi ismereteink szerint - érzékenyebben jelezhet diffúz eltéréseket, és tovább javítja az MR hatékonyságát a hagyományos technikákkal összehasonlítva (oedemaarány, relatív „global enhancement") a Lake Louise-kritériumrendszerben.

Koronarográfiát/angiográfiát és/vagy sziv-CT-t [2] azon betegeknél kell végezni, akiknél olyan distalis szívkoszorúér-aneurysma gyanúja merül fel, amely nem látható jól echokardiogramon. A coronariaaneurysmát kísérô szűküuletek szignifikanciájának meghatározása és nyomon követése céljából stressz-echokardiográfia javasolt, illetve stresszperfüziós sziv-MR is szóba jön.

\section{Kutatási javaslat}

A PIMS akut fázisában a standard vizsgálóeljárásokon (EKG, szívenzimek, echokardiográfia és szükség esetén Holter) túl a CMR-vizsgálatot nem tartjuk indokoltnak. Ugyanakkor kutatási célból fontosnak véljük, hogy minél pontosabb képet kapjunk a betegség kórlefolyásáról, és a kései cardiovascularis események rizikójának előrejelzésére új prognosztikai markereket azonosítsunk. Másrészt feltételezhető, hogy a követés és sport témájában a jelenleg - az egyéb myocarditisek viselkedése alapján - hozott ajánlások túlzóak, ezért ezek felülvizsgálata szükséges majd az új adatok tükrében. Az akut szakaszban történő CMR-t munkacsoportunk kutatási témának javasolja.

\section{Sport}

PIMS esetében a myocardium érintettsége a heveny szakban nagyon gyakori, a betegség kései szövődményei pedig egyelőre nem ismertek, ezért munkacsoportunk 
ajánlása, hogy minden, PIMS-betegség miatt hospitalizált gyermek esetében 3-6 hónappal később történjen részletes szürővizsgálat a cardiovascularis események rizikójának csökkentéséért. Ennek a szürővizsgálatnak része kell, hogy legyen az EKG (szükség esetén terheléses EKG) és az enzimvizsgálatok. CMR javasolt, ha a kontrollvizsgálat során kóros eltérést észlelünk, illetve - a korábbiaknak megfelelően - ha a betegség indulásakor balkamrafunkció-zavart vagy ritmuszavart detektáltunk. Ezen ajánlás alól kivételt képeznek az 5 év alatti, a klaszszikus Kawasaki-betegség tünetei miatt kezelt gyermekek, őket a korábban leírtaknak megfelelően a Kawasakiprotokoll alapján kell követni.

\section{Terápia}

\section{Immunmoduláló kezelés PIMS-ben}

A klinikailag stabil betegek esetében az immunmoduláló kezelés megindítása előtt diagnosztikai értékelést kell végezni, beleértve az egyéb lehetséges fertőző és nem fertőző okokat [2].
Az életveszélyes tünetekkel járó PIMS esetében ne késlekedjünk, az immunmoduláló kezelést akár a teljes diagnosztikai értékelés befejezése előtt el kell kezdeni [2].

A PIMS-ben jártas szakemberek által végzett értékelést követően egyes, csupán enyhe tüneteket mutató betegeknél elegendő lehet a szoros monitorozás immunmoduláló kezelés nélkül $[1,2]$. Ennek feltételei: jó általános állapot; a gyulladásos értékeken kívül nincs szignifikáns laboreltérés; és nincs jele a szervi diszfunkciónak.

Az immunmoduláló terápiák alkalmazása során az ACR „step-up” terápiás ajánlást fogalmazott meg. Az IVIG-et mint első vonalbeli terápiát jelölték meg. A glükokortikoidokat kiegészítő kezelésként javasolják alkalmazni a súlyos betegségben szenvedóknél vagy az intenzív terápia részeként a refrakter betegségben szenvedő betegeknél (2. ábra) [1,2].

A nemzetközi ajánlások publikálását követően jelent meg az a (igaz, megfigyeléses vizsgálat adataira támaszkodó) közlemény, amely szerint a glükokortikoid + IVIG

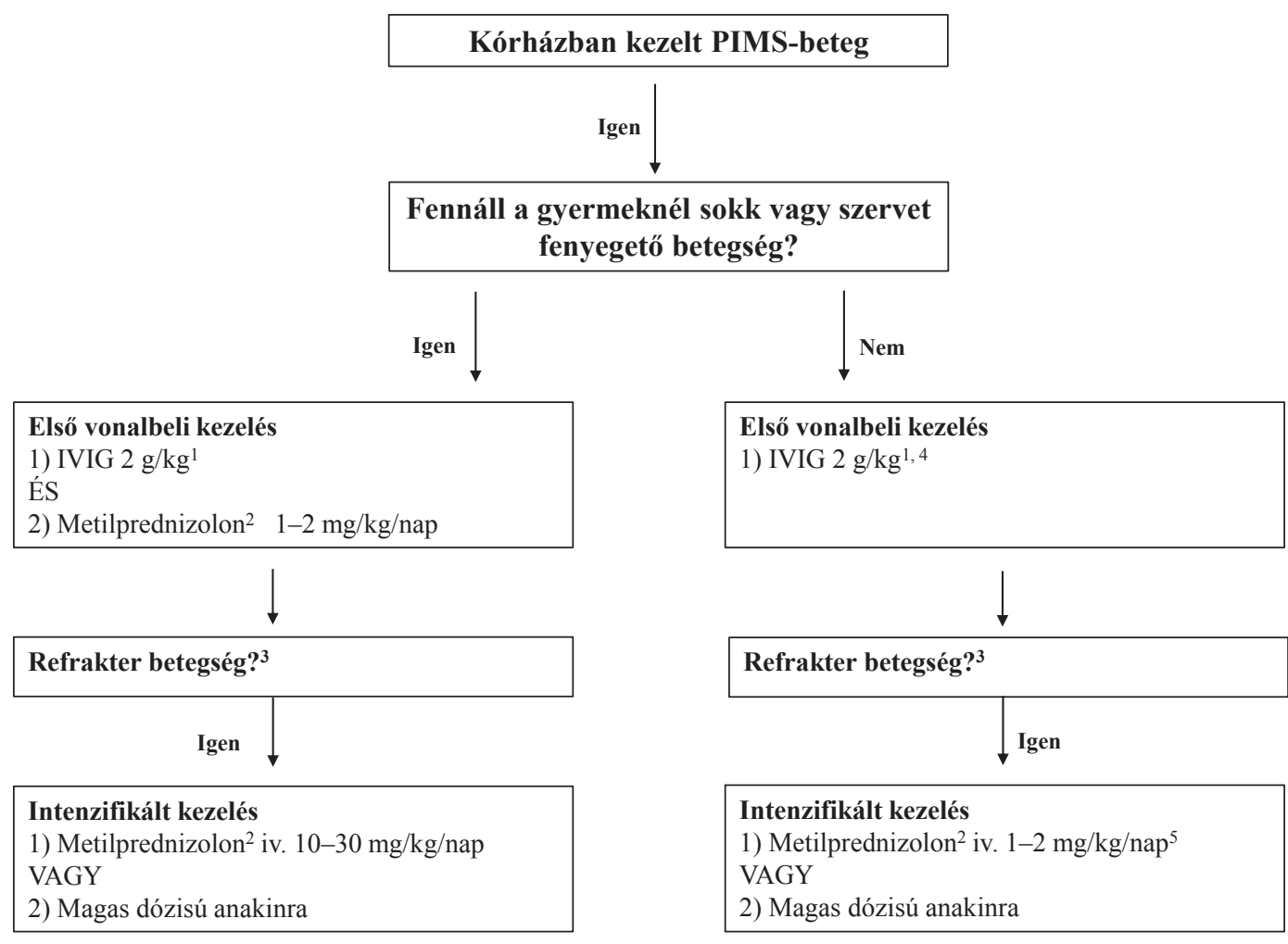

2. ábra

A kezdeti immunmoduláló kezelés algoritmusa PIMS-ben [1, 2]

${ }^{1}$ Az IVIG adagolása: $2 \mathrm{~g} / \mathrm{kg}$ az ideális testtömeg alapján. A szívmúködést és a folyadékstatust az IVIG adása előtt fel kell mérni. Néhány, szívmúködési zavarban szenvedő beteg esetében az IVIG-et osztott adagokban (napi $1 \mathrm{~g} / \mathrm{kg}, 2$ napon át) lehet adni.

${ }^{2}$ Metilprednizolon vagy más szteroid egyenértékú dózisban alkalmazható.

${ }^{3} \mathrm{~A}$ refrakter betegség definíció szerint: tartós láz és/vagy folyamatos és jelentős végszervi érintettség.

${ }^{4}$ Alacsony-mérsékelt dózisú glükokortikoidok (metilprednizolon $1-2 \mathrm{mg} / \mathrm{kg} / \mathrm{nap}$ ) fontolóra vehetők az első vonalbeli terápiában egyes PIMS-betegeknél, akik aggodalomra okot adó jellemzőket mutatnak (betegségre utaló megjelenés, magasan emelkedett BNP, nem megmagyarázatlan tachycardia), és akiknél még nem alakult ki sokk vagy szervet fenyegető betegség.

${ }^{5} \mathrm{Ha}$ a beteg első vonalbeli kezelésként alacsony-mérsékelt dózisú glükokortikoidokat kapott, a metilprednizolon iv. dózisa 10-30 mg/kg/nap legyen intenzifikált kezelésként.

$\mathrm{BNP}=\mathrm{B}$-típusú natriureticus peptid; IVIG = intravénás immunglobulin $(2 \mathrm{~g} / \mathrm{kg}$, max. $100 \mathrm{~g})$; PIMS = gyermekkori sokszervi gyulladásos szindróma 
kombinációs kezelésben részesülő betegek csoportjában kevesebb volt a terápiás kudarc, mint az IVIG-et monoterápiában kapó betegek csoportjában [49].

\section{IVIG}

A nagy dózisú IVIG-gel történő kezelés Kawasakibetegségben az elsőként választandó immunmoduláló terápia [33].

Felnőtt betegek esetében víruspozitív myocarditisben is hatékonynak és biztonságosnak találták az IVIG-kezelést [50]. Vírusnegatív, vagyis autoimmun myocarditisben a különböző immunszuppresszív kezelések mellett az IVIG szintén a terápia része $[51,52]$. Esetszériákban számoltak be SARS-CoV-2-asszociált myocarditises betegek IVIG-kezeléséről. Gyermekkori lymphocytás myositisben régóta alkalmazott terápia az IVIG [53]. Egy szisztematikus irodalomáttekintés alapján a COVID-hoz csatlakozó myocarditisben felnőttkorban a glükokortikoidok mellett szintén gyakran alkalmazott kezelés az IVIG [44].

IVIG-et olyan PIMS-betegeknek kell adni, akik kórházi kezelésben részesülnek, és/vagy megfelelnek a Kawasaki-betegség kritériumainak. A PIMS kezelésére nagy dózisú IVIG-et (2 g/ $\mathrm{kg}$, az ideális testtömeg alapján) kell alkalmazni [2].

A szívelégtelenségben szenvedő betegek esetében szoros monitorozás javasolt, és diuretikumok adására lehet szükség az IVIG-terápia mellett. Súlyos balkamrafunkció-zavar jelei esetén az IVIG osztott adagokban (napi 1 $\mathrm{g} / \mathrm{kg}, 2$ napon át) is adható $[1,2]$.

Munkacsoportunk megjegyzése: Kawasaki-betegségben rosszabb kimenetelt okozott az osztott adagú IVIG, ezért lehetőség szerint egy dózisban javasolt alkalmazni [33].

\section{Glükokortikoidok}

Súlyos Kawasaki-betegségben a glükokortikoidkezelést sikerrel alkalmazták IVIG mellett [54]. Az olasz PIMSkohorszban az IVIG-rezisztens esetek magas arányáról számoltak be [55], ezért érdemes megfontolni, hogy a szteroidokat első vonalban alkalmazzuk [1].

Posztvirális myocarditisben kemény evidenciák állnak rendelkezésre, randomizált tanulmány igazolta ugyanis a szteroidalapú immunszuppresszív kezelés hatékonyságát [56].

Felnőttkorú betegekben a COVID-hoz csatlakozó myocarditisben az esetek 70\%-ában alkalmaztak glükokortikoidkezelést [44].

PIMS esetében a glükokortikoidkezelés megítélésére esetszériák állnak rendelkezésre [11, 17, 34, 36].

Az ACR-ajánlás alapján a PIMS kezelésére az IVIGgel együtt alacsony-mérsékelt dózisú glükokortikoidokat (1-2 mg/kg/nap) kell adni kiegészítő terápiaként sokk esetén és/vagy szervi károsodást fenyegető betegségben $[1,2]$; a terápia hosszát 2-3 hétben határozták meg („experts’ opinion”) [1].
Az angol ajánlás előnyben részesíti az alább tárgyalandó pulzusglükokortikoid-terápiát, és kiegészítő első vonalbeli kezelésként javasolja a fentieken túl a 12 hónaposnál fiatalabb betegek és a coronariaeltérést mutató betegek esetében [3].

\section{Pulzusglükokortikoid}

Azoknál a betegeknél, akik nem reagálnak az IVIG-re és az alacsony-mérsékelt dózisú glükokortikoidokra, nagy dózisú (10-30 mg/kg/nap), iv. pulzusglükokortikoidterápia alkalmazását kell megfontolni, különösen ha a betegnél magas dózisú vagy többszörös inotrop és/vagy vazopresszorkezelés szükséges $[1,2]$.

\section{Refrakter betegség kezelése}

Refrakternek tekintjük a betegséget, ha a gyermek az IVIG-kezelést követően 24 órával még lázas [3].

A refrakter PIMS-ben szenvedő betegeknél az egyszeri IVIG-dózis ellenére aktív betegség esetén a második IVIG-adag az ACR szerint nem ajánlott, tekintettel az IVIG nagy dózisaival járó volumen-túlterhelés és haemolyticus anaemia kockázatára $[1,2]$.

Az angol ajánlás ezzel szemben elfogadhatónak tartja a második IVIG-kezelést mint terápiás alternatívát a refrakter PIMS kezelésében [3].

$\mathrm{Az}$ alacsony-mérsékelt dózisú glükokortikoidok (1-2 $\mathrm{mg} / \mathrm{kg} / \mathrm{nap}$ ) megfontolhatók a PIMS enyhébb formáiban szenvedő azon betegeknél, akik tartósan lázasak, és tüneteket mutatnak az IVIG egyszeri dózisa ellenére $[1,2]$.

Az NLPR3-inflammaszóma aktivációja és a következményes ILl $\beta$-túltermelés a virális és az autoimmun myocarditis patomechanizmusának is az egyik központi szereplője [57]. Az ARAMIS- és a RHAPSODY-vizsgálatban tanulmányozzák az ILl-blokkolók hatékonyságát myocarditisben és recidív pericarditisben $[58,59]$.

A gyermekreumatológiában számos indikációban alkalmazzuk az anakinrát, amely ILl-receptor-antagonista biologikum. Az anakinrát sikerrel alkalmazták refrakter Kawasaki-betegségben [60]. Esetszériákban beszámoltak sikeres anakinrakezelésról PIMS-ben is [10, 11, 34].

$\mathrm{Az}$ anakinra (>4 mg/kg/nap iv. vagy sc.) alkalmazása javasolt $[1-3]$ :

- a súlyos PIMS eseteiben (a definíciót lásd a következő fejezetben),

- az IVIG-re és glükokortikoidokra refrakter PIMS esetében,

- a makrofágaktivációs szindróma (MAS) tüneteit mutató betegek esetében,

- azon betegek kezelésében, akiknél a glükokortikoidok hosszú távú alkalmazása ellenjavallt.

Az immunmoduláló kezelésre adott terápiás választ és a kezelés fokozatos elhagyását sorozatos laboratóriumi vizsgálatokkal és kardiológiai ellenőrzéssel kell irányítani. Standard terápiára refrakter betegség esetén általában 2-3 hetes kezelési időszakra van szükség, az alkalmazott immunmoduláló terápiá(ka)t fokozatosan építsük le. 
4. táblázat | Terápiás algoritmus

\begin{tabular}{|c|c|c|}
\hline & Definíció & Javasolt terápia \\
\hline & Láz és szisztémás tünetek + & IVIG + \\
\hline \multirow[t]{2}{*}{ Enyhe PIMS } & Normotenzió & - * \\
\hline & $\begin{array}{l}\text { Folyadékpótlásra rendeződő hipotenzió, normális balkamra-funkció, gyermekosz- } \\
\text { tályos kezelés }\end{array}$ & $+3 \times$ IVMP vagy $M P$ \\
\hline $\begin{array}{l}\text { Közepesen súlyos } \\
\text { PIMS }\end{array}$ & $\begin{array}{l}\text { Hipotenzió, amely alacsony dózisú keringéstámogatást igényel, echokardiográfián } \\
\text { nincs jele súlyos balkamrafunkció-zavarnak, nincs légzési elégtelenség, szubinten- } \\
\text { zív osztályos kezelés }\end{array}$ & $\begin{array}{l}+3 \times \text { IVMP majd MP } \\
\left(+ \text { anakinra** }^{*}\right)\end{array}$ \\
\hline Súlyos PIMS & $\begin{array}{l}\text { Súlyos kardiogén sokk } \pm \text { intubáció, szívkoszorúér-aneurysma, tudatzavar/ } \\
\text { encephalopathia, intenzív osztályos kezelés }\end{array}$ & $\begin{array}{l}+3-5 \times \text { IVMP }, \text { majd MP } \\
+ \text { anakinra }(/ \text { infliximab } / \text { tocilizumab })\end{array}$ \\
\hline
\end{tabular}

+ További kezelés szükséges.

- Nincs további teendő.

*Vitálisan stabil, enyhe PIMS-ben megfontolandó az IVIG-monoterápia - 36 órán belül értékeljük újra a gyermek állapotát: ha továbbra is lázas, romlanak a gyulladásos laborparaméterek, akkor fontoljuk meg a glükokortikoidkezelést.

** Romló status mellett makrofágaktivációs szindróma irányába tartó laboreltérések (különös tekintettel a vérképre, a ferritin- és D-dimer-értékre) vagy romló gyulladásos paraméterek (CRP, PCT).

$\mathrm{CRP}=\mathrm{C}$-reaktív protein; IVIG = intravénás immunglobulin $(2 \mathrm{~g} / \mathrm{kg}, \mathrm{max} .100 \mathrm{~g}) ; \mathrm{IVMP}=$ intravénás pulzus-metilprednizolon $(30 \mathrm{mg} / \mathrm{kg} / \mathrm{nap})$; $\mathrm{MP}=$ metilprednizolon (per os vagy parenteralisan, $1-2 \mathrm{mg} / \mathrm{kg} /$ nap, max. $60 \mathrm{mg}$ kezdő dózis, két részre osztva, 14 nap alatt csökkentve); PCT = prokalcitonin; PIMS = gyermekkori sokszervi gyulladásos szindróma

\section{Munkacsoportunk terápiás ajánlása}

A terápiás algoritmust a 4. táblázatban foglaltuk össze. Valamennyi, kórházi kezelést igénylő beteget IVIG-gel kezelünk, $2 \mathrm{~g} / \mathrm{kg}$ dózisban, lehetőség szerint egyszeri infúzióban alkalmazva (12 óra).

Egyéb vasculitisekben a glükokortikoidokat rutinszerüen alkalmazzuk, jótékony hatása a PIMS esetében is egyértelmú. Kawasaki-betegségben bizonyított tény, hogy a glükokortikoidok kiegészítő alkalmazása csökkenti a szívkoszorúér-aneurysma kockázatát, a lázas napok számát, és gyorsítja a gyulladásos laborparaméterek normalizálódását (gyorsabban elérjük a remissziót), a kórházi kezelés idejét, és csökkenti a terápiás költségeket [54]. Egy francia munkacsoport közleménye szerint az IVIG-glükokortikoid-kezelést kapó PIMS-beteg esetében is jobb volt a kimenetel [49]. Mindezen megfontolások alapján nem tartjuk logikusnak, hogy PIMS esetében a glükokortikoidokat csak a nagyon súlyos és a refrakter esetekre tartsuk fenn. A PIMS-betegek a munkacsoport klinikáin IVIG előtt és után pulzus-metilprednizolon (IVMP)-kezelésben (30 mg/kg/nap, összesen 3 napon keresztül) vagy nagy dózisú glükokortikoidot alkalmazó terápiában (1-2 mg/kg/nap) részesülnek.

Amennyiben a beteg 3 napi IVMP-kezelés és IVIG után is lázas, akkor

- ha klinikailag instabil, vagy romlik az állapota, anakinrát alkalmazunk (a klinikai állapottól függően monoterápiában vagy glükokortikoiddal kiegészítve);

- ha stabil, és enyhe tünetei vannak a láz mellett, akkor az anakinra alternatívája rezisztens esetekben az alacsony-közepes dózisú napi vagy másnaponkénti glükokortikoidkezelés.

A súlyos betegségaktivitás meghatározása [3]:

- $40 \mathrm{mg} / \mathrm{kg}$-ot meghaladó folyadékbolus-igény,

- 92\% alatti szaturáció,

- makrofágaktivációra jellemző laboreltérések.
Súlyos betegségaktivitás, életveszélyes állapot esetén indokoltnak tartjuk az első vonalbeli biológiai terápiát. Ki kell emelnünk, hogy a célzott terápiák alkalmazásának indikációját képezi a gépi lélegeztetés, de a célpont az invazív terápiák elkerülése. A kezelés intenzifikációjának szükségessége nem köthető konkrét értékekhez - monitorozzuk szorosan a beteg klinikai állapotát, a laboratóriumi értékeket, és „időben” avatkozzunk közbe!

Elsôsorban az anakinra alkalmazását javasoljuk, de a klinikai kép függvényében - elsősorban standard kezelésre rezisztens betegség esetén - szóba jön infliximab vagy tocilizumab alkalmazása is. A biológiai terápia indikációja reumatológiai kompetencia.

\section{Thrombocytaaggregáció-gátlás, antikoagulálás}

Felnőtt COVID-betegekben a szisztémás immunreakció részeként a D-dimer emelkedett szintjét és a vénás thromboemboliás események gyakoribb előfordulását írták le [61]. Boncolások során a mélyvénás thrombosisok mellett a tüdő macro- és microvascularis thrombosisát észlelték [62]. Egy nagy, retrospektív tanulmányban pedig az antikoagulált betegek jobb túlélését találták [63].

A felnőttekkel összehasonlítva a gyermekkori COVID-betegségben a thrombosis nagyon ritka, még a súlyos esetekben is [64]. Azt lehet mondani, hogy a thrombosis előfordulási gyakorisága a COVID miatt hospitalizált betegek esetében azonos az egyéb okból felvett betegekben leírttal (1/300 vs. 1/200) [65, 66]. Ugyanakkor PIMS-ben komolyabban számolnunk kell a thrombosis kockázatával: 13 év felett a betegek 7\%-ában $(3 / 45)$, az alatt pedig a betegek $1,3 \%$-ában (1/75) fordult elő [15]. Érdemes megjegyezni, hogy a thrombosis súlyos myocarditisben észlelt prevalenciája 6\% [67].

Az ACR ajánlása szerint a PIMS-ben szenvedő betegeknél alacsony dózisú aszpirint (3-5 mg/kg/nap; max. $100 \mathrm{mg} / \mathrm{nap}$ ) kell alkalmazni, és folytatni kell a kezelést 
a vérlemezkeszám normalizálódásáig és a koszorúerek igazoltan normális állapotáig a diagnózist követő $\geq 4$ héttel. Az aszpirinnel történő kezelést kerülni kell olyan betegeknél, akiknek aktív vérzésük van, akiknél jelentős vérzési kockázat áll fenn, és/vagy a vérlemezkeszámuk $\leq 80000 / \mu \mathrm{L}$.

A szívkoszorúér-aneurysmában szenvedő és 2,5-10,0 maximális z-ponttal rendelkező PIMS-betegeket alacsony dózisú aszpirinnel kell kezelni. A $\geq 10,0$ z-pontszámú betegeket alacsony dózisú aszpirinnel és enoxaparinnal (Xa-faktor-szint: $0,5-1,0)$ vagy warfarinnal végzett terápiás antikoagulációval kell kezelni. A PIMS-ben és dokumentált thrombosisban egyaránt szenvedő betegeknél, vagy akiknél az $\mathrm{EF}<35 \%$, enoxaparinnal végzett terápiás antikoagulációt kell alkalmazni, legalább a kórházi elbocsátás utáni 2 hétig. Az ambuláns terápiás enoxaparin hosszabb ideig történő adagolásának indikációi a következők:

- szívkoszorúér-aneurysma >10,0 z-pontszámmal (határozatlan idejü kezelés),

- dokumentált thrombosis ( $\geq 3$ hónapig tartó kezelés a thrombus megszűnéséig) vagy fennálló, mérsékeltsúlyos bal kamrai diszfunkció.

Azoknál a PIMS-betegeknél, akik nem felelnek meg a fenti kritériumoknak, az antithrombocyta- és antikoagulációs terápiás megközelítést a beteg thrombosiskockázatához kell igazítani $[1,2]$.

Munkacsoportunk - az amerikaival szemben - nem javasolja a warfarin alkalmazását. Legalább 5-7 napig tart felépíteni, és addig is LMWH-t kell adni. Szintet kell a felépítés közben ellenőrizni, és tudjuk: egyéb gyógyszerek és az étkezés is befolyásolja az INR-értéket. Rövid távú antikoagulálás esetén (mint PIMS-ben) sokkal biztonságosabbnak tartjuk az LMWH adását.

A Nemzetközi Thrombosis és Haemostasis Társaság gyermekgyógyászati albizottsága (International Society on Thrombosis and Haemostasis, Pediatric/Neonatal Hemostasis and Thrombosis Subcommittee) jelentős thrombosiskockázatot lát a normálérték felső határának ötszörösét meghaladó D-dimer-értékben, ezért jóval aktívabb ajánlást fogalmaztak meg: jelentősen emelkedett D-dimer-érték, illetve egy vagy több rizikófaktor jelenléte esetén is antikoagulációt javasolnak [68] (3. ábra).

Meg kell jegyezni ugyanakkor, hogy gyermekkorban a D-dimer gyulladásos betegségekben erősebb kapcsolatot mutat az immunválasz intenzitásával, mint a thrombosis rizikójával [66]. Sokan meglehetősen megbízhatatlan biomarkernek tartják a thromboemboliás betegségek diagnózisában és rizikóbecslésében, ezért nem javasolják, hogy az antikoagulációs profilaxis szükségességét ezen paraméter alapján döntsük el [66, 69].

\section{A profilaxist minden esetben a rizikótól függően javasolt alkalmazni}

A gyermek egyéni és családi anamnézisének ismerete segíti a rizikóbecslést. A családi anamnézisből kiemelendő az egyenes ágú rokonok között ismert thrombophilia, fiatalkori thromboemboliás esemény, habituális vetélés. A gyermek anamnézisében fontos a korábbi thromboemboliás esemény, esetleges ismert thrombophilia (protein C, protein S, antitrombin-III-deficientia, az V. faktor Leiden-mutációja, II. faktor G20210A, antifoszfolipid-ellenanyagok jelenléte), valamint az esetleges társbetegségek és azok kezelése. Rizikót jelentenek a

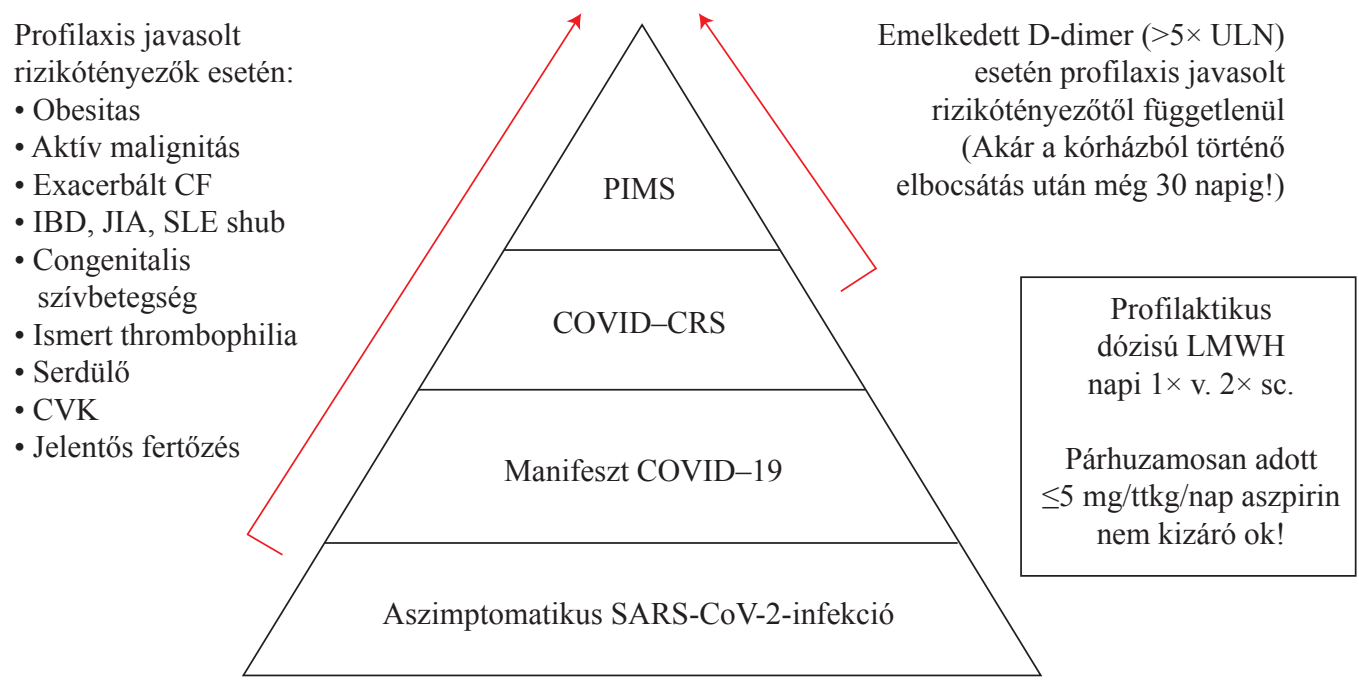

\begin{tabular}{l|l} 
3. ábra & $\begin{array}{l}\text { Thromboembolia-profilaxis PIMS-ben [68] } \\
\text { CF = cystás fibrosis; COVID-19 = koronavírus-betegség 2019; COVID-CRS = koronavírus-betegség-citokinfelszabadulás-szindróma; CVK = cent- } \\
\text { rális vénás kanül; IBD = gyulladásos bélbetegség; JIA = juvenilis idiopathiás arthritis; LMWH = kis molekulatömegú heparin; PIMS = gyermekkori } \\
\text { sokszervi gyulladásos szindróma; SARS-CoV-2 = súlyos akut légúti tünetegyüttest okozó koronavírus-2; SLE = szisztémás lupus erythematosus; ULN } \\
=\text { a normálérték felső határa }\end{array}$
\end{tabular} 
következő társbetegségek, állapotok: obesitas, malignitás és annak kezelése, exacerbált cystás fibrosis, IBD, juvenilis idiopathiás arthritis, SLE, congenitalis szívbetegség, centrális vénás kanül viselése, immobilizáció, hormonkezelés (fogamzásgátló szedése), dohányzás, szepszis, nephrosisszindróma, perioperatív időszak, gépi lélegeztetés. A rizikóbecsléskor figyelembe kell venni a gyermek életkorát is. A serdülőkor után a gyermekek thrombosisrizikója megegyezik a felnőttekével.

Munkacsoportunk javaslata szerint a thrombosisprofilaxisról a családi és az egyéni anamnézis, a beteg klinikai állapota és a veleszületett/szerzett rizikófaktorok értékelése alapján döntsünk. Súlyos és közepesen súlyos PIMS esetén, ha a D-dimer-érték meghaladja a normálérték felső határának ötszörösét, rizikófaktortól függetlenül indokoltnak tartjuk az antikoagulálást. Egyéb esetben egy vagy több rizikófaktor csatlakozása esetén javasolt az LMWH-profilaxis. Az aszpirinkezelés során az ACRajánlást javasoljuk követni.

A thrombosisprofilaxis megkezdése előtt figyelembe kell venni a gyermek esetleges vérzéskockázatát is: például alacsony thrombocytaszám, aktuálisan beültetett centrális vénás kanül, egyéb ismert vérzékenység. A terápiás döntést befolyásolja a gyermek vesefunkciója is. Beszükült vesefunkció esetén LMWH helyett standard heparin (frakcionálatlan) alkalmazása javasolt iv. (az anti-Xa-aktivitás céltartománya: $0,1-0,35 \mathrm{U} / \mathrm{ml}$ ).

$\mathrm{Az}$ antikoaguláns kezelés mellett javasolt mechanikus thrombosisprofilaxis (kompressziós harisnya) alkalmazása is.

\section{Antivirális és antibakteriális kezelés}

A PCR-vizsgálattal vagy antigénteszttel SARS-CoV2-pozitivitást mutató, PIMS-ben szenvedő gyermekekben megfontolandó az antivirális kezelés, az elsóként választandó antivirális szer a remdesivir. Minden betegben parenteralis antibiotikumkezelés indítása javasolt, ezt a klinikai kép, illetve a tenyésztési eredmények alapján kell megválasztani, illetve leállítani. Azoknak a gyermekeknek, akik teljesítik a toxikus sokk szindróma kritériumait, a széles spektrumú antibiotikum mellett klindamicint is kell adni. A kezdeti mikrobiológiai vizsgálatok eredményeinek elkészültét nem szükséges megvárni a nagy dózisú szteroidkezelés, illetve az IVIG-terápia elindítása elött [3].

Munkacsoportunk véleménye szerint antivirális kezelésre csak kivételesen ritkán van szükség. Az akut COVID-betegség is járhat hyperinflammatióval, amely a PIMS klinikai képére is emlékeztethet. Ezeket nem tartjuk valódi „overlap ” szindrómának.

\section{A hazaengedés feltételei}

A jó általános állapotú, legalább 24 órája láztalan, stabil cardialis funkcióval rendelkező beteg bocsátható otthonába. A PIMS-beteg követése javasolt a hazabocsátás után 1-2 héttel, majd 6 hét múlva, az ellenőrzés alkalmával szív-ultrahangvizsgálatnak is történnie kell. Azoknál a betegeknél, akik esetében coronariaérintettség is fennáll, illetve valamilyen szerv múködésének támogatását igényelték, multidiszciplináris követés szükséges, amelyben gyermekkardiológusnak és gyermekreumatológusnak is részt kell vennie [3].

Anyagi támogatás: A közlemény megírása, illetve a kapcsolódó kutatómunka anyagi támogatásban nem részesült.

Szerzői munkamegosztás: C. T.: A hipotézis kidolgozása, a kézirat megszövegezése. A. N., P. A., G. Á., A. L., K. J., Cs. M., E. B., H. Zs., K. Kr., K. R., K. Ki., K. V., M. B., P. T., Sz. Zs., T. A., T. K., T. And., Ó. B., V. H., V. Cs., W. P., Sz. Z., K. G., Sz. A.: A kézirat összeaállítása, véleményezése. A cikk végleges változatát valamennyi szerző elolvasta és jóváhagyta.

Érdekeltségek: A szerzőknek nincsenek érdekeltségeik.

\section{Irodalom}

[1] Henderson LA, Canna SW, Friedman KG, et al. American College of Rheumatology clinical guidance for multisystem inflammatory syndrome in children associated with SARS-CoV-2 and hyperinflammation in pediatric COVID-19. Version 1. Arthritis Rheumatol. 2020; 72: 1791-1805.

[2] Henderson LA, Canna SW, Friedman KG, et al. American College of Rheumatology clinical guidance for multisystem inflammatory syndrome in children (MIS-C) associated with SARSCoV-2 and hyperinflammation in pediatric COVID-19. Version 2. Arthritis Rheumatol. 2020 Dec 5. Doi: 10.1002/art.41616. [Epub ahead of print]

[3] Harwood R, Allin B, Jones CE, et al. A national consensus management pathway for paediatric inflammatory multisystem syndrome temporally associated with COVID-19 (PIMS-TS): results of a national Delphi process. Lancet Child Adolesc Health 2021; 5: 133-141. [Erratum: Lancet Child Adolesc Health $2021 ; 5: \mathrm{e} 5$.

[4] Nijman RG, De Guchtenaere AD, Koletzko B, et al. Pediatric inflammatory multisystem syndrome: Statement by the Pediatric Section of the European Society for Emergency Medicine and European Academy of Pediatrics. Front Pediatr. 2020; 8: 490.

[5] Kanegaye JT, Wilder MS, Molkara D, et al. Recognition of a Kawasaki disease shock syndrome. Pediatrics 2009; 123: e783e789.

[6] Dominguez SR, Friedman K, Seewald R, et al. Kawasaki disease in a pediatric intensive care unit: a case-control study. Pediatrics 2008; 122: e786-e790.

[7] Ahmed M, Advani S, Moreira A, et al. Multisystem inflammatory syndrome in children: a systematic review. EClinicalMedicine 2020; 26: 100527

[8] Inciardi RM, Lupi L, Zaccone G, et al. Cardiac involvement in a patient with coronavirus disease 2019 (COVID-19). JAMA Cardiol. 2020; 5: 819-824.

[9] Long B, Brady WJ, Koyfman A, et al. Cardiovascular complications in COVID-19. Am J Emerg Med. 2020; 38: 1504-1507.

[10] Belhadjer Z, Méot M, Bajolle F, et al. Acute heart failure in multisystem inflammatory syndrome in children (MIS-C) in the context of global SARS-CoV-2 pandemic. Circulation 2020; 142: 429-436.

[11] Whittaker E, Bamford A, Kenny J, et al. Clinical characteristics of 58 children with a pediatric inflammatory multisystem syndrome 
temporally associated with SARS-CoV-2. JAMA 2020; 324: 259-269.

[12] Godfred-Cato S, Bryant B, Leung J, et al. COVID-19-associated multisystem inflammatory syndrome in children - United States, March-July 2020. Morb Mortal Wkly Rep. 2020; 69: 10741080.

[13] Hoang A, Chorath K, Moreira A, et al. COVID-19 in 7780 pediatric patients: a systematic review. EClinicalMedicine 2020; 24 100433

[14] Toubiana J, Poirault C, Corsia A, et al. Kawasaki-like multisystem inflammatory syndrome in children during the Covid-19 pandemic in Paris, France: prospective observational study. BMJ 2020; 369: m2094.

[15] Feldstein LR, Rose EB, Horwitz SM, et al. Multisystem inflammatory syndrome in U.S. children and adolescents. N Engl J Med. 2020; 383: 334-346.

[16] Gruber CN, Patel RS, Trachtman R, et al. Mapping systemic inflammation and antibody responses in multisystem inflammatory syndrome in children (MIS-C). Cell 2020; 183: 982-995.el4.

[17] Swann OV, Holden KA, Turtle L, et al. Clinical characteristics of children and young people admitted to hospital with Covid-19 in United Kingdom: prospective multicentre observational cohort study. BMJ 2020; 370: m3249.

[18] Hanson KE, Caliendo AM, Arias CA, et al. Infectious Diseases Society of America guidelines on the diagnosis of COVID-19: serologic testing. Clin Infect Dis. 2020 Sep 12; ciaal343. Doi: $10.1093 / \mathrm{cid} / \mathrm{ciaa} 1343$. [Epub ahead of print]

[19] Weisberg SP, Connors T, Zhu Y, et al. Antibody responses to SARS-CoV2 are distinct in children with MIS-C compared to adults with COVID-19. medRxiv 2020 Jul 14. Doi: 10.1101/2020.07.12.20151068

[20] Rostad CA, Chahroudi A, Mantus G, et al. Quantitative SARS CoV-2 serology in children with multisystem inflammatory syndrome (MIS-C). Pediatrics 2020; 146: e2020018242.

[21] Centers for Disease Control and Prevention. Options to reduce quarantine for contacts of persons with SARS-CoV-2 infection using symptom monitoring and diagnostic testing. CDC, Dec 2, 2020. Available from: https://www.cdc.gov/coronavirus/ 2019-ncov/more/scientific-brief-options-to-reduce-quarantine. html [accessed: January 31, 2021].

[22] Cheng HY, Jian SW, Liu DP, et al. Contact tracing assessment of COVID-19 transmission dynamics in Taiwan and risk at different exposure periods before and after symptom onset. JAMA Intern Med. 2020; 180: 1156-1163.

[23] Kim MC, Cui C, Shin KR, et al. Duration of culturable SARS CoV-2 in hospitalized patients with COVID-19. N Engl J Med. 2021; 384: 671-673.

[24] Korea Centers for Disease Control and Prevention. Findings from investigation and analysis of re-positive cases. May 19, 2020. Available from: https://www.cdc.go.kr/board/board. es? $\mathrm{mid}=\& \mathrm{bid}=0030 \&$ act $=$ view $\&$ list $\_$no $=367267 \&$ [accessed January 31, 2021].

[25] Li N, Wang X, Lv T. Prolonged SARS-CoV-2 RNA shedding: not a rare phenomenon. J Med Virol. 2020; 92: 2286-2287.

[26] Dong Y, Mo X, Hu Y, et al. Epidemiology of COVID-19 among children in China. Pediatrics 2020; 145: e20200702.

[27] Han MS, Choi EH, Chang SH, et al. Clinical characteristics and viral RNA detection in children with coronavirus disease 2019 in the Republic of Korea. JAMA Pediatr. 2021; 175: 73-80.

[28] Denning DW, Kilcoyne A, Ucer C. Non-infectious status indicated by detectable IgG antibody to SARS-CoV-2. Br Dent J. 2020; 229: 521-524.

[29] Iyer AS, Jones FK, Nodoushani A, et al. Dynamics and significance of the antibody response to SARS-CoV-2 infection. MedRxiv Prepr Serv Heal Sci. 2020 Jul 20. Doi: $10.1101 / 2020.07 .18 .20155374$

[30] Melendez E, Whitney JE, Norton JS, et al. A pilot study of the association of amino-terminal pro-B-type natriuretic peptide and severity of illness in pediatric septic shock. Pediatr Crit Care Med. 2019; 20: e55-e60.

[31] Lippi G, Salvagno GL, Guidi GC. Cardiac troponins in pediatric myocarditis. Pediatrics 2008; 121: 864.

[32] Baker P, Leckie T, Harrington D, et al. Exercise-induced cardiac troponin elevation: an update on the evidence, mechanism and implications. Int J Cardiol Heart Vasc. 2019; 22: 181-186.

[33] McCrindle BW, Rowley AH, Newburger JW, et al. Diagnosis, treatment, and long-term management of Kawasaki disease: a scientific statement for health professionals from the American Heart Association. Circulation 2017; 135: e927-e999.

[34] Capone CA, Subramony A, Sweberg T, et al. Characteristics, cardiac involvement, and outcomes of multisystem inflammatory syndrome of childhood (MIS-C) associated with SARS-CoV-2 infection. J Pediatrics 2020; 224: 141-145.

[35] Tracewski P, Ludwikowska KM, Szenborn L, et al. The first case of pediatric inflammatory multisystem syndrome temporally associated with SARS-CoV-2 infection (PIMS-TS) in Poland, complicated by giant coronary artery aneurysms. Kardiol Pol. 2020; 78: 1064-1065.

[36] Davies P, Evans C, Kanthimathinathan HK, et al. Intensive care admissions of children with paediatric inflammatory multisystem syndrome temporally associated with SARS-CoV-2 (PIMS-TS) in the UK: a multicentre observational study. Lancet Child Adolesc Health 2020; 4: 669-677.

[37] Ramcharan T, Nolan O, Lai CY, et al. Paediatric inflammatory multisystem syndrome: temporally associated with SARS-CoV-2 (PIMS-TS): cardiac features, management and short-term outcomes at a UK tertiary paediatric hospital. Pediatr Cardiol. 2020; 41: 1391-1401.

[38] Berg J, Kottwitz J, Baltensperger N, et al. Cardiac magnetic resonance imaging in myocarditis reveals persistent disease activity despite normalization of cardiac enzymes and inflammatory parameters at 3-month follow-up. Circ Heart Fail. 2018; 10: $\mathrm{e} 004262$

[39] Maron BJ, Udelson JE, Bonow RO, et al. Eligibility and disqualification recommendations for competitive athletes with cardiovascular abnormalities. Task force 3 : hypertrophic cardiomyopathy, arrhythmogenic right ventricular cardiomyopathy and other cardiomyopathies, and myocarditis. Circulation 2015; 132: e273-e380.

[40] Ripley DP, Musa TA, Dobson LE, et al. Cardiovascular magnetic resonance imaging: what the general cardiologist should know. Heart 2016; 102: 1589-1603.

[41] Tschöpe C, Ammirati E, Bozkurt B, et al. Myocarditis and inflammatory cardiomyopathy: current evidence and future directions. Nat Rev Cardiol. 2021; 18: 169-193.

[42] Grün S, Schumm J, Greulich S, et al. Long-term follow-up of biopsy-proven viral myocarditis predictors of mortality and incomplete recovery. J Am Coll Cardiol. 2012; 59: 1604-1615.

[43] Banka P, Robinson JD, Uppu SC, et al. Cardiovascular magnetic resonance techniques and findings in children with myocarditis: a multicenter retrospective study. J Cardiovasc Magn Reson. $2015 ; 17: 96$

[44] Kariyanna PT, Sutarjono B, Grewal E, et al. A systematic review of COVID-19 and myocarditis. Am J Med Case Rep. 2020; 8: 299-305.

[45] Puntmann VO, Carerj ML, Wieters I, et al. Outcomes of cardiovascular magnetic resonance imaging in patients recently recovered from coronavirus disease 2019 (COVID-19). JAMA Cardiol. 2020; 5: 1265-1273

[46] Vágó H, Szabó L, Dohy Z, et al. Cardiac magnetic resonance findings in patients recovered from COVID-19: initial experiences in elite athletes. JACC Cardiovasc Imaging 2020 Dec 16. Doi: 10.1016/j.jcmg.2020.11.014. [Epub ahead of print]

[47] Halushka MK, Vander Heide RS. Myocarditis is rare in COVID-19 autopsies: cardiovascular findings across 277 postmortem examinations. Cardiovasc Pathol. 2021; 50: 107300. 
[48] Wilson MG, Hull JH, Rogers J, et al. Cardiorespiratory considerations for return-to-play in elite athletes after COVID-19 infection: a practical guide for sport and exercise medicine physicians. Br J Sport Med. 2020; 54: 1157-1161.

[49] Ouldali N, Toubiana J, Antona D, et al. Association of intravenous immunoglobulins plus methylprednisolone vs immunoglobulins alone with course of fever in multisystem inflammatory syndrome in children. JAMA 2021; 325: 855-864.

[50] Ameling S, Bhardwaj G, Hammer E, et al. Changes of myocardial gene expression and protein composition in patients with dilated cardiomyopathy after immunoadsorption with subsequent immunoglobulin substitution. Basic Res Cardiol. 2016; 111: 53 .

[51] Dandel M, Wallukat G, Englert A, et al. Long-term benefits of immunoadsorption in $\beta 1$-adrenoceptor autoantibody-positive transplant candidates with dilated cardiomyopathy. Eur J Heart Fail. 2012; 14: 1374-1388.

[52] Trimpert C, Herda LR, Eckerle LG, et al. Immunoadsorption in dilated cardiomyopathy: long-term reduction of cardiodepressant antibodies. Eur J Clin Invest. 2010; 40: 685-691.

[53] Amabile N, Fraisse A, Bouvenot J, et al. Outcome of acute fulminant myocarditis in children. Heart 2006; 92: 1269-1273.

[54] Wardle AJ, Connolly GM, Seager MJ, et al. Corticosteroids for the treatment of Kawasaki disease in children. Cochrane Database Syst Rev. 2017; 1: CD011188.

[55] Verdoni L, Mazza A, Gervasoni A, et al. An outbreak of severe Kawasaki-like disease at the Italian epicentre of the SARS-CoV-2 epidemic: an observational cohort study. Lancet 2020; 395: 1771-1778.

[56] Wojnicz R, Nowalany-Kozielska E, Wojciechowska C, et al. Randomized, placebo-controlled study for immunosuppressive treatment of inflammatory dilated cardiomyopathy. Circulation 2001; 104: $39-45$

[57] Kraft L, Erdenesukh T, Sauter M, et al. Blocking the IL-1 $\beta$ signalling pathway prevents chronic viral myocarditis and cardiac remodeling. Basic Res Cardiol. 2019; 114: 11.

[58] U. S. National Library of Medicine. RHAPSODY Phase 3 study to assess the efficacy and safety of rilonacept treatment in subjects with recurrent pericarditis. First posted: Nov 9, 2018. Available from: https://clinicaltrials.gov/ct2/show/NCT03737110 [accessed: January 30, 2021].

[59] U. S. National Library of Medicine. Anakinra versus placebo for the treatment of acute myocarditis (ARAMIS). Last update: Dec 4, 2020. Available from: https://clinicaltrials.gov/ct2/show/ NCT03018834 [accessed: January 30, 2021].
[60] Kone-Paut I, Cimaz R, Herberg J, et al. The use of interleukin I receptor antagonist (anakinra) in Kawasaki disease: a retrospective cases series. Autoimmun Rev. 2018; 17: 768-774.

[61] Middeldorp S, Coppens M, van Haaps TF, et al. Incidence of venous thromboembolism in hospitalized patients with COVID-19. J Thromb Haemost. 2020; 18: 1995-2002.

[62] Wichmann D, Sperhake JP, Lütgehetmann M, et al. Autopsy findings and venous thromboembolism in patients with COVID-19: a prospective cohort study. Ann Intern Med. 2020; 173: $268-277$.

[63] Tang N, Bai H, Chen X, et al. Anticoagulant treatment is associated with decreased mortality in severe coronavirus disease 2019 patients with coagulopathy. J Thromb Haemost. 2020; 18: 1094-1099.

[64] DeBiasi RL, Song X, Delaney M, et al. Severe COVID-19 in children and young adults in the Washington, DC Metropolitan Region. J Pediatr. 2020; 223: 199-203.el.

[65] Carpenter SL, Richardson T, Hall M. Increasing rate of pulmonary embolism diagnosed in hospitalized children in the United States from 2001 to 2014. Blood Adv. 2018; 2: 1403-1408.

[66] Del Borrello G, Giraudo I, Bondone C, et al. SARS-CoV-2-associated coagulopathy and thromboembolism prophylaxis in children: a single-center observational study. J Thromb Haemost. 2021; 19: 522-530.

[67] Lin KY, Kerur B, Witmer CM, et al. Thrombotic events in critically ill children with myocarditis. Cardiol Young 2014; 24: 840-847.

[68] Goldenberg NA, Sochet A, Albisetti M, et al. Consensus-based clinical recommendations and research priorities for anticoagulant thromboprophylaxis in children hospitalized for COVID19-related illness. J Thromb Haemost. 2020; 18: 3099-3105.

[69] Biss TT, Brandão LR, Kahr WH, et al. Clinical probability score and D-dimer estimation lack utility in the diagnosis of childhood pulmonary embolism. J Thromb Haemost. 2009; 7: 1633-1638.

[70] Children's Hospital of Philadelphia. Multisystem inflammatory syndrome (MIS-C) - Differential diagnosis - Clinical pathway: emergency, ICU and inpatient. Available from: https://www. chop.edu/clinical-pathway/multisystem-inflammatorysyndrome-mis-c-differential-diagnosis [accessed: February 11, $2021]$.

(Constantin Tamás dr., Budapest, Túzoltó u. 7-9., 1094 e-mail: tamasconstantin@gmail.com)

\section{"Maxima debetur puero reverentia!" (Legszentebb figyelemmel tekints a gyermekkorra!)}

A cikk a Creative Commons Attribution 4.0 International License (https://creativecommons.org/licenses/by/4.0/) feltételei szerint publikált Open Access közlemény, melynek szellemében a cikk bármilyen médiumban szabadon felhasználható, megosztható és újraközölhetö, feltéve, hogy az eredeti szerző és a közlés helye, illetve a CC License linkje és az esetlegesen végrehajtott módosítások feltüntetésre kerülnek. (SID_1) 